\title{
Minerals and Cucumbers in the Sea: International relations will transform the Tongan state
}

\begin{abstract}
Constitution law researcher Guy Powles, a Pakeha New Zealander residing in Australia was not optimistic accurate predictions on "the [Tonga] election which is coming up now in November" could be made (Garrett, 2014). "A man would be a fool to try to guess just where the balance will finish up," he uttered to Jemima Garrett interviewing him for Radio Australia on April 30th 2014 (Garrett, 2014). Picturing the general election seven months away on November 27th 2014, Powles thought devolving the monarch's executive powers to government by constitutional reform was Tonga's priority. Whether it would end up an election issue deciding which way the public voted was a different story, and one he was not willing to take a punt on.

While Tongans and non-Tongan observers focused attention on guessing who would get into parliament and have a chance at forming a government after votes had been casted in the November election, the trying political conditions the state functioned, floundered, and fell in, were overlooked. It was as if the Tongans and Palangi (white, European) commentators naively thought changing government would alter the internationally dictated circumstances a small island developing state was forced to work under.
\end{abstract}

Teena Brown Pulu has a PhD in anthropology from the University of Waikato. She is a senior lecturer in Pacific development at AUT University. Her first book was published in 2011, Shoot the Messenger: The report on the Nuku'alofa reconstruction project and why the Government of Tonga dumped it. 
Nineteen years ago, Maltese professor of economics Lino Briguglio spelled out the vulnerabilities that small island states in pursuit of economic development were subject to, and subjugated by. His 1995 essay is wholly relevant today.

Small size creates problems with public administration. An outcome of this is that SIDS [small island developing states] have to rely on larger states, generally the ex-colonizing country, for specialized aspects of public administration. A related problem is that many government functions tend to be very expensive per capita when the population is small. For example, overseas diplomatic missions of small island states are often unmanned. Another public administration problem in SIDS is that people know each other well, and are often related to each other. This tends to work against impartiality and efficiency in the civil service and against a merit-based recruitment and promotions policy. (Briguglio, 1995, p. 1617).

This essay unravels a Tongan story about minerals and cucumbers in the sea, a descriptor for the political spectrum of noblemen and commoners standing for election to parliament in 2014. It asks a simple question. Will international or internal relations transform the Tongan state? The evidence points to international relations as the dominant driver altering Pacific Island states. However, Tongans alongside Palangi writing about Tonga are absorbed by internal politics, seeing this as the root of reform. The riddle of reforming Tonga to become what, exactly, has been confoundedly theorised by political actors and little understood by the masses.

My paper notes how Tongan politicians and the public are swayed by the bike shed effect, a state bureaucracy condition 
where Cyril Northcote Parkinson argued bureaucrats and organisations give more weight to triviality over important subjects (Northcote Parkinson, 1957). In a nutshell, I contend that Tongans are obsessed with, and surmise about, trifling affairs with regard to national politics. Conversely, the things that really matter, such as international relations transforming how the state operates and the polity and economy of the Pacific Islands region, are too involved to fathom from garnering a government press release, a media sound-bite, and a parliamentary debate aired free on public radio.

\section{Politicians behaving badly}

If ever there was a scrambled translation of Tongan history in the political present, then Sitiveni Halapua was the teller of tales. He translated the Tongan term "Kafataha" to mean a "Cabinet of National Unity," and ran with his invention to show the public (The Tonga Herald, 2014b). He got on radio and in the newspaper talking up a storm on Kafataha. But Kafataha was not a social referent to the state's national executive, a cabinet of ministers. Just as the term's root word Kafa, meaning a sennit rope braided from coconut fibre, had no practical use for governing the country; not unless Halapua was pointing out Tongans wore ta'ovala, meaning mats around their waists in parliament requiring a rope to tie it up.

If he was attempting metaphorical dexterity by stretching the rope of human imagination to get his Kafataha cabinet of national unity figure of speech, it did not work at tying up political loose ends. If anything, when it came to the dismal fall-out between Halapua and his Democratic Party leader 'Akilisi Pohiva, and the fact Halapua was dumped by Pohiva from the party list of candidates running in the 2014 election, Kafataha had uncoiled against him. The rope came undone, tripping up Halapua in full flight of Kafataha speechmaking. 
The Tonga Herald gave a description of what this website thought "Kafataha" or "Cabinet of National Unity" meant in practice (The Tonga Herald, 2014b).

Halapua's slogan was "Kafataha" or "Cabinet of National Unity." It was a strategy to reel Nobles and non-PTOA representatives into a broad power-sharing deal, and would have provided an in-road for the PTOA to take the reins of government. (The Tonga Herald, 2014b).

Kafataha "was a strategy" for "a broad power-sharing deal" to govern Tonga (The Tonga Herald, 2014b). Kalino Latu for the Tongan news website New Zealand Kaniva Pacific concurred with The Tonga Herald caption. The idea of "a broad power-sharing deal" correlated with "a coalition" government of parliamentarians from both class divisions, the people's and the nobles' representatives (The Tonga Herald, 2014b; Latu, 2014d).

Under Halapua's proposal all parliamentarians would work together as a coalition. According to Halapua, members would have a conscience vote and could vote against their caucus. The gist of the idea was there would be no need for an opposition party because, in Dr Halapua's words, all parliamentarians would work according to principles of love, honesty and peace. (Latu, 2014d).

'Akilisi Pohiva had a different spin. The Democratic Party leader read Kafataha as a "political doctrine," and one that was rumoured to be incompatible with the party line, which was said to be the reason behind Halapua getting dropped from the party register (Radio New Zealand, 2014c). 
It is a pity, the difference between Steven Halapua and myself but we can't afford, at this point in time, to come into the House with two different political doctrines because when we come to formulate policies we have to have only one. ('Akilisi Pohiva cited in Radio New Zealand, 2014c).

Then there was Halapua's angle. To Radio New Zealand International, he inferred that "coalitions" offered an English language simile for understanding how Kafataha functions (Radio New Zealand, 2014b). By this, coalition government was a political arrangement he had noticed taking place in "other Commonwealth countries," and naturally deduced why not Tonga too (Radio New Zealand, 2014b).

The idea of one party - win and get the majority and run everything - I think it is an old fashioned way of thinking. The world has changed and I have seen that in New Zealand, in Australia and in other Commonwealth countries where it is important for people to think about forming coalitions. (Sitiveni Halapua cited in Radio New Zealand, 2014b).

In the exact same radio interview, Halapua switched boats in midstream by saying no, "the word coalition" was not what he meant at all (Radio New Zealand, 2014a). He did not "want to use the word coalition" for Kafataha because Kafataha alluded to "working towards some common goal ... negotiated with others," which by and large echoed the logic holding together a coalition government in Commonwealth states (Radio New Zealand, 2014a). 
It is about building, development and working towards some common goal and that common goal has to be negotiated with others who are willing to work with us, and that is why I use the word 'kafataha.' I don't want to use the word coalition because we don't have a party system. (Radio New Zealand, 2014a).

Halapua had gotten his Kafataha in a twist. I mean to say, his conniving on how to form a government and be central to its composition wedged him in the age-old riddle of which came first, the chicken or the egg? Which do we sort out first, party candidates for the election or ministers for an incoming cabinet? What gets publicised first, the party policies or a cabinet of national unity charter? What campaign gets pushed first, the party leader or nominations for prime minister?

A Tongan economist who lived in Hawai'i, America while employed at the East-West Center in Honolulu for a number of years, Halapua had direct social memory of the United States as a federal constitutional republic. He knew American democracy was buttressed by two major political parties, the Democratic Party and the Republican Party, which formed the legislature's two chambers of Congress, the Senate and the House of Representatives.

Moreover, he had an inkling that political parties did not overrule American democracy. The enormity and complexity of running fifty states and one federal district making up a large country with the population size of 313.9 million people was controlled by multiple governments at federal, state, and local municipal and district levels. What ruled the roost was not different party doctrines competing to influence the state, but government and "governmentality," which meant the act of governing (Foucault, 1988, 2004). 
When speaking from his small island developing state of birth, he wrote off Tonga as not practicing "a party system" by any way, shape, or form (Radio New Zealand, 2014a). This was not true, and nor was the Kafataha crusade ethical and practicable in its will to mobilise state governance towards thinking that in Tonga, "there would be no need for an opposition party" in parliament (Latu, 2014d).

Had Halapua been a political scientist, instead of an economist, he would have known that systematic power designed to annihilate political opposition and civil forms of organised resistance encompassed a host of names such as tyranny, despotism, dictatorship, totalitarianism, and autocracy. Sometimes, wiping out "an opposition party" from the political structure was called martial law and military junta, especially when executed by organisations of an extreme nationalist or religious fundamentalist nature.

The Kingdom of Tonga was none of these. Therefore, why call for nationalist regression, aggression, and oppression as Tonga's way forward? Preposterously, why try to make out taking away the "need for an opposition party" was a just political act exemplifying higher "principles of love, honesty and peace" (Latu, 2014d). Halapua was talking in circles, and in the long-winded moment his Kafataha had wound up with haphazard ideas that did not tie together rationally.

Officially, Tonga had five registered political parties from the commoner class that had contested various elections; the longest running being the Human Rights and Democracy Movement instituted in 1992 of which the former Prime Minister from 2006 to 2010 Feleti Sevele was a member elected to parliament in the 2005 election, along with six others of this party.

The Democratic Party of the Friendly Islands led by 'Akilisi Pohiva was formalised in 2010 two months before the election, originally taking out twelve of the seventeen people's 
representatives seats. Now it was trimmed down a tad with Sangster Saulala exiting the party to join the Tu'ivakano government as an independent member of parliament. Then recently four parliamentarians, including Halapua, were chopped as candidates for the 2014 election. On top of that pile was the deputy leader, 'Isileli Pulu, who according to the New Zealand Kaniva Pacific website, got the boot from the party leader. Hence, it was tricky to estimate how they would fear at the polls second time around.

It was not as Halapua said that "we don't have a party system" in Tonga, but rather, the class group who mobilised effectively as a political party was the nobility. The nine nobles' representatives to the legislative assembly practiced an established set of party principles of firstly, no dissent among the ranks when voting as a bloc; and secondly, loyalty to the monarch and the constitutional declaration granting their entitlement as the Kingdom of Tonga's title and estate holders. With clear-cut principles and policies defining the landed gentry's identity, constitutional privilege, and position of authority in the national hierarchy as representatives of the crown and ruling class, it was evident the nobles knew who they were, how they were related, and what they were about in parliament.

How would a political party of commoners outflank Tongan tradition by reinventing history from below to possess superior authority and power to the national hierarchy? By Tongan social norms, was it considered necessary to raze to the ground a hierarchy of titled men, who by the monarch's tutelage, were symbolic of Tonga's unique sovereignty?

Halapua ought to have edited his indictment that in Tonga "we don't have a party system" to reflect historical correctness (Radio New Zealand, 2014a). At the 2010 general election, 38,447 voters took to the seventeen constituency polls to elect the people's representatives to parliament (Matangi Tonga, 
2010). An overwhelming majority of 25,873 voters gave their single vote in the first past the post system to independent candidates, not political party candidates (Matangi Tonga, 2010). A statistical comparison revealed the truth about voter behaviour. Halapua was thoughtlessly mistaken. Political parties were included in the electoral system, but Tongans voted for independent candidates in their constituencies more than party candidates.

Tongans were legendary at voting for kainga, their blood relatives, kinfolk, affine, and even close family friends and community fellows. Policies their kainga promoted rated second to the fact that relationship connections figured highly in determining how a vote was cast. No matter how many foreign meddlers disguised as benevolent aid donors and their army of consultants swore that public education would strengthen democracy, Tongans continued to vote for their own people, their kainga, in a system meant to lure them into voting for policies. Did Western political thought provide a reasonable, workable model for reorganising Tongan voting patterns? (Osborne, 2014). I seriously doubt that.

Fleetingly, 'Akilisi Pohiva attuned his Democratic Party sensor to the region, a surprising shift in subject matter from disputing points of political trivia against Sitiveni Halapua, 'Isileli Pulu, Sione Taione, and other men he erased as his party's candidates for parliament. I say fleetingly because Pohiva's concentration span on what was happening regionally in other Pacific Island states materialised as a one-off moment (Bola-Bari, 2014a, 2014b; Anneberg and Kata, 2014; Graue, 2014; Haywood-Jones, 2009). Sceptically, his favourable opinion of Fiji's Prime Minister Frank Bainimarama read like a publicity stunt to incite and excite media attention in an election year. 
I admire him [Fiji Prime Minister Bainimarama] for that. He has been able to make things happen and take development to the people, which had not happened for years. He had the will to make things happen, to make reality of things that were planned over the years. Every government needs to have the political will to implement positive changes. Even though there have been recommendations made by the International Monetary Fund and other organisations; this is a big problem, not only here in Tonga, but in many small developing countries in the region. There is a lack of will to implement things, to connect things and make them happen. It is something that we, as a party, are looking at because we also want to form the next government. We must have the political will to make changes. This government does not have that. I know some of my own party members do not have that. It's an issue that we will continue to face but we must start doing things right. We must have the checks and balance system; we must have transparency. This is the ultimate aim. I like that Prime Minister Bainimarama has done in Fiji in making things happen. And my government will make the necessary changes, as recommended by so many international teams that have done country analysis on Tonga. (Pohiva cited in Tonga Daily News, 2014b).

"We must have the political will," avowed 'Akilisi Pohiva to Fijian reporter Iliesa Tora of Tonga Daily News at a Tongan government luncheon in Nuku'alofa on June 25th 2014 (Tonga Daily News, 2014b). The political will to "make [what] necessary changes, as recommended by so many international teams that have done country analysis on Tonga," Pohiva was not coming out with concisely (Tonga Daily News, 2014b). 
His political ace was the change card, which three months off from the general election he played close to his chest. However, he did drop a few hints as to what he was plotting and that his political scheme if elected to government had not shifted from the 2010 election campaign four-years prior (Moala, 2014b). Pohiva was wedded to thinking that Tonga's democracy was incomplete, and to finish the job he would get rid of the nine nobles' seats if he could get away with it. If he could not, then scaling down the number of nobles in the House was plan B.

Whatever Pohiva meant by "political will," one signal became clear (Tonga Daily News, 2014b). It was now his catchphrase which he bandied around loosely to argue that the Tu'ivakano government lacked the backbone and determination to "take development to the people," unlike Fiji's Prime Minister Frank Bainimarama whom Pohiva held in high regard (Tonga Daily News, 2014b). The Democratic Party leader was busy inventing social memory to engineer a media scoop that framed Fiji as the development success story measured against a failed Tongan economy. The contrariness of Tonga's long standing pro-democracy politician venerating Bainimarama, Fiji's military coup leader non-elected to his country's premiership, underlined the double-standards and rich irony that Tongan electioneering had fast become doubted, disbelieved, and distrusted for.

The Democratic Party divorce between the party leader and subordinate others provided a public spectacle stalked by media and published in news headlines. In addition to this, it also created a Tongan example of Parkinson's theory on triviality, or the bike shed effect as it has been called (Northcote Parkinson, 1957). To give a summation, Parkinson made a compelling case that bureaucracies and organisations spend excessive amounts of time discussing petty concerns of 
no great significance and advantage to the group they work for or represent as an affiliate.

At one committee meeting, Parkinson observed members spent a few minutes discussing their company's investment in a nuclear reactor, the highest priority on the agenda (Shapley and Shubik, 1954). The lowest priority, building a bike shed for company staff, stimulated a lengthy debate and some quarrelling over what colour to paint the bike shed. The bike shed effect occurs when people cannot grasp the entirety, complexity, and detail of an important topic (Gough, 2011). They therefore turn their attention to trivialities where everyone, as opposed to a knowledgeable few, can contribute expert discussion on "all kinds of uselessness" (McCourt, 1996). Thus, last season's Democratic Party falling apart at the seams and getting a makeover by introducing new model candidates for the election catwalk, definitely stirred up something of the bike shed effect.

In the 21 st century, if international relations was truly reconfiguring the Pacific Islands region and Tonga under its Orwellian omnipotent force, then what was foreign policy? (Orwell, 1949). Put bluntly, under the Tu'ivakano regime Tonga had accommodated the Ma'afu mindset to manoeuvring on the foreign affairs front. The Minister for Lands Lord Ma'afu, a former military officer and aide-de-camp to King Taufa'ahau Tupou IV, practiced real politik, meaning tactics of power politics to strategise Tonga's vantage point (Mearsheimer, 2014; Mindle, 1985; Yurdesev, 2006).

Coordinated in Ma'afu's political thinking were three principles. To start with, foreign policy had to benefit Tongan national interests. Subsequent to this, national interests was the equivalent concept and practice for national security. Lastly, every country, no matter how big or small, had the right to have their national interests recognised regionally 
among Pacific Island states, and internationally at the world parliament of the United Nations.

On noting that, what did Tongan foreign policy come down to by Ma'afu's style of practice? Why was it vital for prospective parliamentarians looking to form the next government to study how Tonga's international relations shaped up now, before fronting for ministerial duty in January 2015?

\section{Manoeuvring at the macro-level}

A critique is not a matter of saying that things are not right as they are. It is a matter of pointing out on what kinds of assumptions, what kinds of familiar, unchallenged, unconsidered modes of thought the practices that we accept rest.

Michel Foucault

Michel Foucault's logic made sense in a Western state and society such as modern day France, his national country: "A critique does not consist in saying that things aren't good the way they are. It consists in seeing on just what type of assumptions, of familiar notions, of established and unexamined ways of thinking the accepted practices are based. ...To do criticism [therefore] is to make harder those acts which are now too easy" (Foucault, 1988).

But "to do criticism" in Tonga as a Native Tongan whether nobleman or commoner had a catch to it, as any Tongan born and raised in the homeland state could explain (Foucault, 1988). In this small island developing state where the "accepted practice" was for the state to reproduce social hierarchy, the pecking order of men who assumed authority was seldom called out and publicly named "unexamined" 
convention (Foucault, 1988). Expressly a critique of the monarch's executive powers as the head of state and military commander in chief did not exist in public criticism. What did occur was a surrogate practice of making "harder those acts which are now too easy" (Foucault, 1988).

Put plainly on "the micro-level of interpersonal relationships" men of customary authority, the nobility in particular, jostled and elbowed each other in parliamentary debate. The objective was for one noble to raise their public profile at the expense of another as the more clued-up gentleman of the upper class who knew about modern politics and society (De Souza, 2014). As a method of exerting influence over noble peers and commoners in the House, the real purpose was to amass popularity by appealing to parliamentarians and the general public as a better nobles' representative; one who participated in the world outside of an insular class bubble, and seemed adaptable to working beyond the constraints of a nobleman's smugness and comfort zone.

Of course this was a form of public campaigning for the nobility disguised as a critique of the nobles' pecking order in the legislative assembly; a self-evaluation of "who's who in the zoo" in respect of who needs to be bumped off, nudged out, and shafted along to make room for new zoo characters. ${ }^{1}$ Considering the commoner public registered on the general roll did not vote in the nobles' election, surveying the nobility go hammer and tongs in the House was the predominant way

Who's who in the zoo?

This is the Master of Philosophy thesis title by Richard Pamatatau, journalism lecturer in the School of Communications at Auckland University of Technology. Pamatatau's thesis investigates the journalism methods by which New Zealand's elite are framed, reported, and disseminated in the social and weekend pages of prominent newspapers such as The New Zealand Herald. Pamatatau is of Mauke, Cook Islands descent, and was the former Pacific correspondent for Radio New Zealand who reported from Tonga on the 2010 general election. 
they could judge who's in and who's out by their assessment as outsiders and observers; not that the opinions of the commoner class swayed how the upper class voted during their in-house election. Only fools and horses would be gullible enough to believe Tongan commoners had any effect over which nobles were chosen from among their own class group for parliamentary duty.

Ruth De Souza's opinion that politics in general across the globe had to move away from "the micro-level" towards a "macro-level of [understanding and influencing] international relations" rang true in Tonga's regressive and inward looking case. "I call for our politics to extend beyond the micro-level of interpersonal relationships to consider the meso-level of institutions and nations and the macro-level of international relations. We need it now more than we've ever needed it," wrote De Souza (De Souza, 2014). But who in Tonga's legislative assembly was adjusting the political lens outward to look at the international landscape of "institutions, nations and relations," and who by contrast was heading in the opposite direction, backwards to the narrow-minded periphery of politicking the personal and by doing so, personalising politics? (De Souza, 2014).

The first week for Tonga's 2014 legislative assembly convened for four days from Monday July 21st to Thursday July 24th. Wednesday afforded an opportunity to thrash out amendments to the general regulations of the exclusive economic zone of Tonga (Kingdom of Tonga, 2007). Tonga's Territorial Sea and Exclusive Economic Zone Act 2007 was up for debate with Lord Ma'afu, the Minister for Lands and Natural Resources heading the legislative assembly deliberations by taking an offensive position. Ma'afu had brought the amended act into the House. His words and doggedness showed he was fixated on members of parliament 
correctly understanding the legal and regulatory framework, and answering their queries in a short, sharp tone and tenor.

Running strictly to army time, Ma'afu wanted legislature endorsement from the majority. This was his single-minded mission. A quarter of a decade as an officer in His Majesty's Armed Services, the lands minister manoeuvred a military tactic by executing a calculated plan with precision. He grew impatient with politicians spouting off two seneti [cents] worth of surmising, and did not have all day to dilly-dally around with inaccurate rambling and long windedness.

At this Wednesday July 23rd session where Lord Ma'afu's adjustments to general regulations were formally scheduled, Lord Nuku, the noble's representative for 'Eua took the lead on putting in his two seneti [cents] and pushing for a dollar change. In other words, Nuku baited Ma'afu as the Minister for Lands and Natural Resources and a fellow nobles' representative to get a bite. That, he definitely got from a feisty, forthright Ma'afu who appeared in no mood for beating around the bush on what he saw to be straightforward, logical improvements.

The following verbatim excerpts in the Tongan language taken from the Tonga Hansard report for the House session on Wednesday July 232014 have a brief English synopsis (Tonga Hansard, 2014b). The summation condenses the main point of discussion which Nuku and Ma'afu respectively convey in their dialogical exchange, and is by no means a word-for-word translation.

In the first section, the Speaker of the House Lord Fakafanua made a lame attempt to settle the score by sitting on the fence and stating the obvious; that is, the nobles Nuku and Ma'afu were disputing amendments to the regulations because they had interpreted the matter differently. If the truth be told, Fakafanua, a young, naïve, and politically inexperienced noble would not want to get in the middle of a 
scrap between two nobles of seniority and status, and was better off keeping his nose out of it, which he probably sensed given his pintsized intervention as the speaker. Notably, he did get his facts botched. It was not the actual nitty-gritty of the intended changes that was being contested here.

Nuku's argument digressed from evaluating whether the alterations were defensible and procedural. He put forward that changing one clause on the general regulations of Tonga's exclusive economic zone meant taking into consideration that the other clauses and parts of the Territorial Sea and Exclusive Economic Zone Act 2007 would also need to be corrected to align with the modifications. Ma'afu abruptly begged to differ, stating that this was certainly not the case for amending clause 10 under Part II of the exclusive economic zone of Tonga.

Nuku: 'Eiki Sea, ko e tokanga pe 'a e motu' a ni ia koe' uhi he founga ko 'eni ke mea' i pe Sea ko 'ene liliu pe ha kupu kuo uesia pea mo e to e kupu. Pea kapau leva te tau liliu he 'oku pehe pe anga koe fa'u 'o e lao hange ko e ngaahi tu'utu'uni ko 'eni 'oku tau 'au ki ai Sea, ko 'etau hang ape 'o liliu ha fo'i fotunga ha fo'i kupu 'e taha 'oku fekau 'aki pe 'u kupu katoa mei he 'uluaki 'o a'u ki he fakamuimui. Pea kapau te tau hanga 'o liliu ko e me'a ia ko e 'oku fai ki ai 'a e hoha'a Sea, kapau leva 'oku fekau'aki 'a e u kupu pea ... 'oku faka'uhinga pehe 'a e 'uhinga ko e hono hoko atu ko e ' $i$ he Komiti Kokato, koe 'uhi ko 'ene fetongi pe ha kupu 'oku 'I ai 'a e ki'i liliu ia 'i he natula ko e 'o e lao pea 'oku feinga leva ke fakatatau ki he me'a ko e 'oku fai ki ai ko e 'a e 'uhinga na'e fokotu'u mai ai Sea. (Tonga Hansard, 2014b, p. 10).

If we are going to change any regulations, or any part of the law, it is going to affect all other parts in relation to that change. 
Ma'afu: Sea, ko eku fakatonutonu pe ki he Hou'eiki Nopele Sea ko e fo'i Lao Fakaangangaanga ia ko 'eni 'oku vahevahe ia ki he konga 'e 10, pea kapau 'e to'o 'a e ki'i fo'i konga ia 'e 1 hono alea 'i pea liliu ia kei lele lelei pe ki'i fo'i lao ia Sea 'oku 'ikai ke 'i ai ha uesia ia ai Sea, malo Sea. (Tonga Hansard, 2014b, p. 10).

No, the new regulations have come in only to change Part 10. If you only change one part of it, you do not need to go back and change the whole lot.

Nuku:

'Eiki Sea, 'oku ou ... malo 'aupito 'a e 'omai ko 'eni 'o e me'a 'oku 'uhinga fakalukufua atu au 'eni ia ki he ngaue Fale Alea 'oku 'ikai ke u nofo taha pe au 'i he lao ko 'eni. Ko e 'uhinga pe 'a 'aku ia koe 'uhi ko e founga ngaue ko 'eni ko e 'oku tau ngaue' aki 'i he Tohi Tu'utu'uni Sea, kapau ko e me'a ia 'a e 'Eiki Minisita ia ki he lao kehekehe pe ia, pea ko e Feitu'una pe te ke hanga 'o aofangatuku ka 'oku fai 'a e hoha'a atu ia koe' uhi ko e natula fakalukufua ko e ngaue Fale Alea Sea, malo 'aupito. (Tonga Hansard, 2014b, p. 10).

That is how the Minister interprets it, and that is why parliament is here; to make sure the Minister comes back so we can debate the issue.

Fakafanua: Fakamalo atu Hou'eiki. Hou'eiki 'oku fie fakamanatu atu heni na'e 'ikai ke u fa'u 'e au 'a e Tu'utu'uni ko 'eni, ko e me'a pe 'eni kuo pau ke ... ko e Tu'tutu'uni pe 'eni kuo pau ke tau muimui ki ai, pe 'i he 'eku faka'uhinga 'oku 'ata pe ia, 'oku ha mahino pe ai 'a e faikehekehe 'i he kupu mo e Lao Fakaangaanga Kaikehe, hange pe ko e me'a na'aku 'uhinga atu ki ai kimu'a 'e malava $p$ eke mou malanga fakalukufua pea kapau 'e fakafoki mai pe ki he tefito'i kupu 'eni na'e 'uhinga ai hono tukuhifo ki he Komiti Kakato. Kau ai 'a e ngaahi kupu kehe 'e uesia 'i hano liliu 'a e kupu koi a, kapau 'oku mahino ia ki he Fakafofonga 'o e Hou'eiki Nopele. (Tonga Hansard, 2014b, p. 10). 
That is how people look at regulations and misinterpret it, so the regulations are going back to the full committee. The two nobles are disputing the regulations. They have a different interpretation of it.

Two reasons have prompted me to cite this passage from the Tonga Hansard transcript detailing a debate in the House between Lord Nuku, the noble's representative for 'Eua and Lord Ma'afu, the number two noble's representative for Tongatapu and Minister for Lands and Natural Resources. First and foremost, there was never any substantive argument over the changes to general regulations under clause 10, Part II of the exclusive economic zone of Tonga in the Territorial Sea and Exclusive Economic Zone Act 2007. In fact the revisions were not clearly spelled out in the House session, and nor were their specificity and the necessity for making changes weighed up by parliamentarians in a detailed examination. If anything, the opposition bench sat quietly compliant with Sione Taione, the people's representative for Tongatapu 8 and a Democratic Party member going into bat for Lord Ma'afu's side by defending the minister's amendments.

In one way, it could be said that the content of clause 10 admonished any figurative punch ups in parliament by way of politicians' word battles. Hence, "10 General Regulations" on Tonga's exclusive economic zone of 200 miles began by affirming: "The King may from time to time, by Order-inCouncil, make regulations for all or any of the following purposes." Stop tape, rewind the very thought of criticising the monarch's executive powers in Privy Council propped up by Law Lords, and what was it that Guy Powles, the constitution law researcher uttered to Radio Australia? "The dramatic change has occurred [in Tonga's system of power]. The door has been opened" for Western liberal democracy, or something or other (Garrett, 2014b). 
Life in the legislature revealed a twofold political reality was busy at work. The opposition could see at a glance the Minister for Lands and Natural Resources was meticulously putting law changes in order to line up his ducks; meaning Ma'afu was getting his ministry's affairs organised to fully house deep sea mineral exploration and exploitation before the conclusion of the Tu'ivakano government's four-year term in December of 2014. He planned to permanently embed seabed minerals into the ministry's function and purpose. By doing so, the succeeding government could not easily back out on the current regime decision to commit the Tongan state to deep sea mining.

Earlier in the year, Lord Ma'afu with the backing of Prime Minister Tu'ivakano and cabinet deliberately divorced the Ministry of Environment and Climate Change. He now operated as a stand-alone Ministry of Lands and Natural Resources. A context-specific logic propelled the separation. First of all, an official government line was put to the public. The Ministry of Foreign Affairs and Trade, Prime Minister Lord Tu'ivakano's portfolio, had appropriated environment and climate change to group together six departments under one super ministry of environment, energy, natural disaster, climate change, the meteorological office, and information (Tonga Daily News, 2014b). Orchestrated by a rationale that under Foreign Affairs and Trade the divisions would gain greater access to international aid donations also existed the allusion "of generating income through this new department to fund the new foreshores for Ha'apai," divulged the Deputy Prime Minister Samiu Vaipulu (Tonga Daily News, 2014b).

Underpinning the official spiel was Lord Ma'afu's selfstyled real politik. By no uncertain terms did he baulk at severing environment and climate change from lands and natural resources. Why not? Considering the late King George Tupou V appointed Ma'afu the Minister for 
Environment and Climate Change in 2009, one year after he first entered parliament, conferring on him the responsibility to capacity build a new ministry with little funding, why did he not shriek over the split up? Originally environment and climate change was Ma'afu's baby that he nurtured from infancy; one which had given him a foot on the international stage as a South Pacific climate campaigner at the 15th session of the United Nations Framework Convention on Climate Change in Copenhagen 2009 (Brown Pulu, 2013a, 2013b).

The succinct answer was real not imagined power politics had adjusted his focus. Lord Ma'afu was exclusively and explicitly after deep sea minerals. Freeing up an individual Ministry of Lands and Natural Resources detached from an environmental protection arm alleviated the long-running tension which had escalated between the lands' geologists coveting deep sea mineral extraction, opposed to the climate change activists desiring strict conservation of natural resources (Brown Pulu, 2014). Now, who possessed state authority over natural resources in the restructuring exercise? The words of the late French philosopher Jacques Derrida rang out: "In short, you will never know" (Derrida, 1999). But Ma'afu did know that the legislative and regulatory framework remained the same, granting his portfolio of lands and natural resources the ministerial power to manage and administer state natural resources, including ocean borders and territories, which housed the new baby he was raising named seabed minerals.

Subsequent to this, from a prospective position the Democratic Party were not singly acquiescent to Ma'afu's revisions on general regulations of Tonga's exclusive economic zone for the sake of being agreeable and cooperative fellow legislators. In this sense, political reality was far more pragmatic than idealistic. The Ministry of Lands and Natural 
Resource's pursuit of seabed minerals on the country's behalf was a development policy which 'Akilisi Pohiva if elected prime minister in 2014 and an incoming Democratic Party government would undoubtedly continue, without reconsidering its high-prioritisation and merit as a national strategy for economic growth.

Second, Ruth De Souza's "call for our politics to extend beyond the micro-level of interpersonal relationships to consider the meso-level of institutions and nations and the macro-level of international relations," had a case in point with the Nuku and Ma'afu spat (De Souza, 2014). Aside from the parliamentary tit-for-tat staging two nobles disagreeing; two nobles who were meant to be playing cricket for the same traditional team that customarily won the national match against the commoner opposition, a binary of "micro-level interpersonal relationships" and "macro-level international relations" transpired between them (De Souza, 2014). Their politics were streets apart, dispelling the myth that because the nobility voted solidly as a bloc of nine parliamentary seats on legislative matters they naturally shared uniform and unchanging values and visions. This simplistic deduction was untrue.

Looking at "the micro-level of interpersonal relationships," Lord Nuku was the noble transmitter of such a stand (De Souza, 2014). His interchange with the Minister for Lands and Survey turned Lord Ma'afu into the opponent because in all honesty, Nuku was upping his own credibility during a publicly broadcasted parliamentary debate as the more knowledgeable noble of law and regulation design. But without a concrete examination of the exact clauses and parts of the Territorial Sea and Exclusive Economic Zone Act 2007 Nuku believed should be tweaked to bring into line the revisions Ma'afu had submitted to the House, there was no disputation of the law. Conversely, bickering emerged over 
whose interpretation on how to go about revamping the law was correct, Nuku or Ma'afu.

To contextualise "the micro-level of interpersonal relationships" fuelling the Nuku versus Ma'afu squabble, here were two nobles' representatives for the four seats assigned to the main island where over sixty percent of the country's population of 104,941 resided (De Souza, 2014). At the 2010 election, Ma'afu had been voted into parliament by his class peers as the number two noble for Tongatapu. Nuku, by comparison, got last place in the Tongatapu electorate at number four, and was therefore assigned the seat for 'Eua Island.

To tease out the "micro-level" even further, Nuku won a by-election for the 'Eua seat on August 2nd 2012 because Lord Lasike, the original noble who held the seat was dismissed from his job as Speaker of the House (De Souza, 2014). With Lasike's sacking, he also lost his nobles' representative seat in parliament. Ma'afu at number two outflanked Nuku at four in terms of winning the popular vote, but the incisive query was would the ranking order change at the nobles' in-house election set for November 27th 2014?

It was no secret that both Nuku and Ma'afu were strong contenders for re-election. The grand prize, however, was entering the House as the number one noble's representative for Tongatapu having secured the majority of votes. Number one led the nobility and had considerable sway over how the bloc would vote. Nuku was not shy to push his own barrow, staking out territory as the nobility's strongest parliamentary debater. Whether the arguments he mooted for contention were on point or not was peripheral to the fact that he had grown a public reputation as the most vocal noble who gave his opinion on every matter raised in parliament. Nuku's verboseness versus Ma'afu's reserved manner of generally speaking only to his ministry's core business in short, terse 
bursts put their communication techniques at odds, while exhibiting the range and reach of leadership styles.

Contrastingly "the meso-level of institutions and nations and the macro-level of international relations" was earmarked for Lord Ma'afu (De Souza, 2014). Out of necessity he disregarded "the micro-level of interpersonal relationships" in parliament between the nobility and likewise, across class groups of commoners and nobles (De Souza, 2014). The machinery of government had become increasingly bureaucratised during the Tu'ivakano regime with an emphasis on recruiting technocrats, meaning technical experts in senior management and administration positions, to run the state. Early on in the government's 2010 to 2014 term, Ma'afu found his forte to aggressively chase seabed minerals with every intention of making it a high-priority development industry for the state.

There were obvious hold-ups. Nationally, the Tongan state did not have a distinct law on seabed minerals and a regulatory framework to protect the state from liability for environmental loss and damage. Regionally, Pacific Island states had shifted towards climate adaptation, disaster preparedness, and renewable energy as collective urgencies thus, outing seabed mineral exploration and exploitation as a development goal that an individual state decided to go after not inter-government organisations. Internationally, Tonga's appointment to the International Seabed Authority council in July of 2014 as one of the "eighteen members elected according to the principle of ensuring an equitable geographical distribution of seats" was fundamental to progressing seabed mining for the country (ISA, 2014a).

The relationship web of infiltrating and connecting "institutions, nations, and international relations" in respect of seabed minerals had mechanised the Minister for Lands and Natural Resources into a bureaucratised political actor 
focused on processes and outcomes (De Souza, 2014). Operating in a different work mode to his fellow nobles' representative to parliament Lord Nuku, where in the scope of "meso-level and macro-level" politics would Lord Ma'afu have the time of day to concentrate on "the micro-level of interpersonal relationships" between politicians promoting themselves for re-election? (De Souza, 2014).

\section{Borderlines on the ocean}

"How can we define the line because our boundaries are so close, as in the case of Fiji?" (Tonga Hansard, 2014, p. 38). Lord Ma'afu put the question to the House. His quiz was proposed as a thought provoker not a thought provider. Here was a probe that set out to occupy another's pondering around delimiting Tonga's ocean borders, rather than provide information on how it is practically done. Tagged on the end of a pithy response to Lord Nuku's soliloquy, it was meant as a full stop, curbing any further digression away from discussing changes to general regulations in the Territorial Sea and Exclusive Economic Zone Act 2007.

The short answer was no. Ma'afu was gesturing to a tale of two countries navigating sea currents of twists and turns. At this point in time, there was no state method for delimiting ocean borders between Tonga and six neighbouring countries flanking its exclusive economic zone. Particularly, sorting out sea boundaries with Fiji had a history of "fertile tension" (Spivak, 1990, p. 99). In 2005, Fiji contested Tonga's national sovereignty over two underwater reefs, and had counter claimed to the International Seabed Authority of which it was currently a council member that the Minerva Reefs belonged to them not Tonga (Brown Pulu, 2014; Radio New Zealand, 2005; Coutts, 2011).

This was compounded by the fact that ocean borders collided. Tonga's 200 mile exclusive economic zone ran up 
against Fiji's boundary. To extend the country's ocean area beyond that by requesting an additional continental shelf territory of up to 500 kilometres outside of the exclusive economic zone was pushing the limits (Brown Pulu, 2014). To be concise, Tonga and Fiji had put continental shelf submissions into the United Nations Commission on the Limits of the Continental Shelf (CLCS) for assessment. The applications overlapped, a polite way of saying Tonga and Fiji's respective continental shelf assertions ploughed into each other. In the end, they wanted to seize the same extended sea territory in the Lau Basin.

The pieces of the narrative fitted together. It became comprehensible why Ma'afu had been fixated on Tonga's July 2014 election to the International Seabed Authority council to match Fiji's re-election. A political leverage strategy to get on par with Fiji at the world council for seabed governance, Tonga's representation fired a double-edged plan. The Minister for Lands and Natural Resources was dead serious about growing Tonga's effectiveness as a small island developing state sponsor of seabed mining companies in international waters outside of the country's 200 mile exclusive economic zone. Having every opportunity at international, regional, and country-to-country dialogues to improve relations with the Fijian government, also a state sponsor competitor wanting profitable seabed mining contracts, was vital to keeping the peace with the eastern border neighbour and clearing up ocean boundary disputes.

Ma'afu's response to Nuku in the legislative assembly on Wednesday 23 July 2014 about the difficulty of drawing borderlines between small island developing states, which were really "large ocean states," rolled over the parliamentarians' heads like an incoming tide (Mark Brown cited in Perrottet, 2011). But he put the hard question out 
there: "How can we define the line?" (Tonga Hansard, 2014, p. 38).

In many ways, his frame of inquiry did more to expose a dearth of understanding inside the legislature as to how and why international authority controls country-to-country relations between Pacific Island states all grappling with the same complex situation. In the 21 st century, the Pacific Ocean was legislated as if it were landed territory under an international governance regime specified by the United Nations Convention on the Law of the Sea 1983.

How in the "meso-level and macro-level" of "institutions, nations, and international relations" could Tonga best manoever its quest for seabed minerals as a high-priority development goal by adapting the Law of the Sea 1983 to national legislation? Ma'afu's logic was clear-cut. For the Tongan state to be assured of business sustainability as a seabed minerals sponsor necessitated that its sea boundaries were safe and secure by delimitation according to national and international law.

Nuku: ... 'uhinga foki hange ko e me'a ko eni kapau 'oku kei laumalie pe 'a e fo'i mape ko ia 'a Tupou 1. Ka 'oku mahino kiate au 'i he' ene tu'u ko ia heni ko 'etau ngaue 'aki eni e vahevahe he konivesio 'a e UN [United Nations]. Ka ko 'eku tokanga pe ki ai pe 'oku tau kamata mei fe hotau ngatangata' anga. Pe 'oku tau kamata 'i he fo'i mape ko ia he 1887 'a ia 'oku kamata foki ia 'i tahi, ko hotau boundary ia 'oku tau ngata ai. Ka ko e konivesio foki ko eni mahalo 'oku tatau fakalukufua ia ki he, mei hotau matafanga 'o lele ai e u maile ko ia 'alu atu 'o 200 pe 'oku tolungofulu tupu. Ka ko 'eku fie lave' i pe 'e au ia pe ko fe koa e me'a 'oku tau kamata totonu mei ai. Malo 'Eiki Minisita. (Tonga Hansard, 2014b, p. 38).

In the time of King Tupou I, they first decided Tonga's ocean boundaries in 1887 . The United Nations 
Convention [of the Law of the Sea] decides boundaries. The United Nations Convention says its 200 miles.

Ma'afu: Sea, ko e fehu 'i mahu'inga ia 'oku me'a mai ki ai e Nopele he ko e tu'unga ia 'oku tau 'i ai he taimi ni. Tau recognize 'etautolu e fo'i puha na'e declare ko ia 'e Tupou 1 pea 'oku tau to e fakamo'oni ki he konivesio ko e he Law of the Sea 'a e ko e 'oku 'ai e 200. Pea 'oku te'eki ai ke to e fu'u, 'osi kamata pe ka 'oku te'eki ai ke lava faka'osi 'etau talanoa mo hotau 'u kaunga api. Tau pehe hange ko Fisi [Fiji] 'a eni ko e 'oku hoko kia tautolu. Te tau ta fefe fo'i laini [line] 'oku tau fu'u vaofi. Ka ko e 'uhinga, ko e fehu'i ko e 'a e Nopele, 'oku lolotonga ngaue ki ai e Pule'anga he taimi ni ke sio ange ko fe 'a ngatangata' anga ko e 'o Tonga ni. He kapau 'e tuku mai ia ki Tonga ni te tau kamata tautolo 'uluaki 'ai e puha ia pea tau toki lau mei ai e u malie 'e 200 kitu'a ka he 'ikai foki ke tali ia 'e he kaunga' api mo e me'a. Ka 'oku lolotonga fai e ngaue lahi ki ai 'a e Pule'anga he taimi ni Sea. Malo Sea. (Tonga Hansard, 2014b, p. 38).

I agree with Tupou I and the Law of the Sea Convention defining a 200 mile boundary. We have not finished deciding our ocean boundaries. How can we define the line because our boundaries are so close, as in the case of Fiji? The government is working on it now to decide the ocean boundaries.

If the "government is working on it now to decide the ocean boundaries," as Lord Ma'afu made publicly known in the legislature, then what exactly was the Tongan state doing? More concisely, what was the Minister for Lands and Natural Resources fixing to do seeing deep sea minerals fell under his ministerial dominion? (Tonga Hansard, 2014b, p. 38). "Working on it now" meant a division of labour across two fields, governance and politics (Tonga Hansard, 2014b, p. 38). When operating the two at the same time the trickier cog in 
the machinery of government was politics, often dressed up as diplomacy.

It was well known that Tonga's diplomatic handling of the Minerva Reefs quarrel with Fiji produced dismal failure. To be contritely blunt, Tonga had exercised no diplomacy, tact, and negotiation over the matter. Instead, consecutive governments of Feleti Sevele and Lord Tu'ivakano used the same three-step method. First, mobilising the Tongan navy to patrol and safeguard the reefs; second, submitting claims to the United Nations that Minerva fell under Tonga's sovereign jurisdiction; and third, brandishing around the 1972 Royal Proclamation of King Taufa'ahau Tupou IV declaring property ownership of the Minerva Reefs, which were renamed Teleki Tokelau and Teleki Tonga.

Real politik talks with a strategic approach on sorting out how two bickering small island developing states could strike a win-win compromise never saw the light of day. From Fiji's 2005 opposition, to Tonga's territorial sovereignty laid down on the Minerva Reefs, right up to the present-day, diplomacy was waiting to be put to work. In the meantime, three public arguments gave reasons as to why the Tonga and Fiji dispute had erupted with no solution in sight.

The first was an international relations contention traced to the realism school of thought. Fiji's militarisation under the Bainimarama regime was arguably an act of strengthening national security. Rod Alley, a Pakeha New Zealander and strategic studies research fellow at Victoria University of Wellington saw the clash was therefore motivated by Fijian aggression.

Fiji was using this dispute to flex their muscles and to show their neighbours that Fiji can stand in its own corner and declare its interests. (Rod Alley cited in One News, 2011). 
Second came the economic growth line of reasoning. Here, it was speculated that seabed minerals and "fishing rights," which signalled to tuna stocks, had triggered money-making competition for natural resources that could be traded for profit.

It is suspected the conflict is based around valuable underwater mineral deposits and fishing rights. Fiji and Tonga have now gone to the United Nations for help to avoid a potentially serious situation. (One News, 2011).

Lastly, and perhaps the more convincing argument, was authored by Hanns Buchholz in his 1987 book, Law of the Sea Zones in the Pacific Ocean. Buchholz evidenced that Fiji stood to lose a substantive area of ocean territory if they conceded to Tonga's sovereign jurisdiction over the Minerva Reefs. But he also affirmed that "the Tongan claims have to be recognized today" because at the time of the 1972 Royal Proclamation of King Taufa'ahau Tupou IV, no objection was raised by any Pacific Island state (Buchholz, 1987, p. 85).

In those days nobody opposed this [1972 Royal] proclamation [of King Taufa'ahau Tupou IV], and therefore the Tongan claims have to be recognized today. Taking these islands as the basis for the application of equidistant lines with neighbouring states, Tonga will gain approximately 194,000 square kilometres of sea area, and Fiji will lose 64,000 square kilometres. Additionally, the maritime borders of Tonga and New Zealand will touch. (Buchholz, 1987, p. 85). 
Buchholz's judgement was the one that Ma'afu was socialised by, and sensitive to. Of course the Minister for Lands and Natural Resources wholeheartedly believed that "the Tongan claims have to be recognized today" under international law, that is, the Convention of the Law of the Sea 1983, and by world governance organisations such as the Commission on the Limits of the Continental Shelf (CLCS) and the International Seabed Authority (ISA) (Buchholz, 1987, p. 85). Ma'afu's cultural and political socialisation as a noble of the realm, a nobles' representative to parliament, a cabinet minister, and a Tongan citizen had shaped and styled his moral reasoning that Tonga was the rightful sovereign state of which the Minerva Reefs were part of.

However, Tonga's Minister for Lands and Natural Resources was also dissuaded from aggressively charging into a volatile situation with Fiji. His moral reasoning rooted in a context-specific socialisation experience were the brakes constraining him. To explain, Ma'afu had Fijian connections to the Lau Islands along with many Tongan nationals whose familial ancestries were marked by histories of social exchange, trade, and reciprocity, forming an extended community between the two island groups and geographically adjacent neighbours, Tonga and Lau.

Indeed, he sympathised with the Fijian government's stand that Minerva Reefs belonged to "the people of Ono-i-Lau in Fiji's Lau Group as the traditional fishing ground of their ancestors for centuries" (Radio New Zealand, 2005). Tongan fishermen avowed the reefs were a "traditional fishing ground" that their "ancestors" had used "for centuries" too (Radio New Zealand, 2005).

In the midst of watching Tonga and Fiji attacking and discrediting one another's sovereign claim, he maintained his composure as a high-ranking Tongan noble. He had not surrendered to Fiji and he was no ordinary nobleman, but 
rather, he was the holder of the Ma'afu title which made him the head of Tonga's oldest and senior confederation of chiefs, the Ha'a Havea Lahi. His social duty and political obligation were therefore firmly placed with King and country. In a nutshell, both his traditional and ministerial responsibility amounted to protecting and defending the Kingdom of Tonga's integrity and territory under the head of state and commander in chief, King Tupou VI.

Ma'afu exercised caution on striking a balance between engineering diplomatic talks with the Fijian government alongside putting his ministry's house in order for ocean borders and seabed mining by amending general regulations under national law. Added to this, were the pragmatics of resolving what Tonga had historically believed were national sea boundaries with the Convention on the Law of the Sea 1983; the presiding legal framework prescribing an entirely different method for calculating a country's exclusive economic zone and extended continental shelf. Hanns Buchholz explained Tonga's unique situation.

Additionally, one would have to interpret the 1887 sea borders as straight baselines, which is not in accordance with the new Convention on the Law of the Sea. Apart from that, the neighbouring states - Fiji, Wallis and Futuna, Western Samoa, American Samoa and Niue - would be affected and would definitely not agree. (Buchholz, 1987, p. 85).

It was Lord Nuku who raised the August 24th 1887 declaration of King George Tupou I on Tonga's sea boundaries with Lord Ma'afu in the parliamentary session of July 23rd 2014. The ocean coordinates and contents were mapped out as "all, islands, rocks, reefs, foreshores and waters lying between the fifteenth and twenty-third and a half degrees of 
south latitude and between the one hundred and seventy-third and the one hundred and seventy-seventh degrees of west longitude from the Meridian of Greenwich" (Kingdom of Tonga, 2014, p. 1).

Nuku's argument was the Convention of the Law of the Sea 1983 outflanked King George Tupou I's 1887 declaration, rendering it null and void in terms of practical applicability to mapping out ocean borders between Tonga and neighbouring states. Ma'afu's riposte was he agreed with the two different sets of principles a century apart used to establish Tonga's maritime territory, the monarch's 1887 declaration as well as the Law of the Sea 1983.

Similar to Lord Nuku's stand, Hanns Buchholz stressed Tonga's 1887 declaration was out of kilter with the Convention on the Law of the Sea 1983, which took precedence as the international ruling delimiting all countries' ocean borders. Related to this disjuncture was the fact that under the 1887 declaration, national sea boundaries cut into the exclusive economic zones of six Pacific Island states, including New Zealand, who "would definitely not agree" with Tonga's 19th century cartography (Buchholz, 1987, p. 85).

Contrariwise, Tonga's Minister for Lands and Natural Resources voiced he found agreement with both, despite the present-day reality that international law invalidated royal declarations and proclamations that did not align with their judgement on how the world's seas and oceans were to be fairly divided up among states for exclusive economic zones and outer limits of the continental shelf. Which brings me to query that given Lord Ma'afu was seeking a political opening to engage Fiji in diplomatic talks on reconciling the Minerva Reefs quarrel and colliding ocean borders, how might he integrate Tonga's 1887 royal declaration into national legislation, the Territorial Sea and Exclusive Economic Zone Act 2007? Could this be considered anything other than an origin 
moment in Tonga's modern history; one when the country's first constitutional monarch issued a 19th century pronouncement on sea boundaries which today was not legally binding or endorsed under international law? (One News, 2011).

I stress this because the Kingdom of Tonga Submission to the Commission of the Continental Shelf through the SecretaryGeneral of the United Nations, April 2014 which was authorised by the Minister for Lands and Natural Resources began by noting: "The Kingdom of Tonga is proud to have the longest continuous legal claim of historic title to maritime domain in the World" (Kingdom of Tonga, 2014, p. 1). This starting point to Tonga's United Nations application for an extended continental shelf in the Lau-Colville Ridge which intersected with Fijis claim in the same ocean territory was in direct reference to "The Royal Proclamation issued by His Majesty George Tubou, King of Tonga, on 24 August 1887" (Kingdom of Tonga, 2014, p. 1). To recapitulate, the lead-in highlighted that King George Tupou I as head of state laid down "national jurisdiction by the Kingdom of Tonga" defining what he believed to be Tonga's "maritime domain in the World" (Kingdom of Tonga, 2014, p. 1).

Ma'afu had taken a distinct approach to contextualising Tonga's continental shelf claim to the Lau-Colville Ridge than his predecessor, fellow noble and former Minister for Lands under the Feleti Sevele government, Lord Tuita. He was historicising and politicising sea boundaries by emphasising the Kingdom of Tonga's unique point of maritime difference to Fiji and neighbouring Pacific Island states. "The Kingdom of Tonga is proud to have the longest continuous legal claim of historic title to maritime domain in the World" (Kingdom of Tonga, 2014, p. 1). That mattered momentously to the point it would remain at the forefront of the country's history, culture, and identity as Tonga's edge over competing claims. 
Hence, the critical inquiry was twofold. If Ma'afu was after international recognition from the United Nations Commission on the Limits of the Continental Shelf (CLCS) that Tonga had "the longest continuous legal claim of historic title to maritime domain in the World," then how might acknowledgement of historical fact be manoeuvred by the Minister for Lands and Natural Resources to his country's negotiating advantage with Fiji? (Kingdom of Tonga, 2014, p. 1). Subsequent to this, would international recognition grant Tonga political leverage to adapt principles from the 1887 Royal Declaration on "historical title to maritime domain" and the 1972 Royal Proclamation over the Minerva Reefs in national legislation such as the Territorial Sea and Exclusive Economic Zone Act 2007, and quite possibly, the future instatement of a seabed minerals law? (Kingdom of Tonga, 2014, p. 1).

Whatever the case, Lord Ma'afu was figuring out by intuition and intellect the contours and conflicts of ocean borders in relation to seabed mining. In many respects, his foresight and vision had shown to be far beyond the latitude of fellow parliamentarians and previous ministers appointed the lands and natural resources portfolio. Anticipating the prime minister and cabinet changeover after the November 27th 2014 election, Ma'afu would be a hard act to follow and measure up to for any incoming minister, nobleman and commoner alike.

\section{Minerals and cucumbers in the sea}

On Friday 25th July 2014, the Government of Tonga press released that "today for the first time [Tonga] has been elected by State Members of the International Seabed Authority to a seat on the Authority's Council" (Government of Tonga, 2014). "The Assembly, in an uncontested election, renewed almost half of the membership of the Authority's 36-member Council, 
for a four-year term from 2015 through [to] 2018" with Fiji being re-elected for a second term, and Tonga newly elected (International Seabed Authority, 2014b). As the authorising and regulating body of seabed mining licenses and resource extraction activities at high seas under the Convention on the Law of the Sea 1983, the International Seabed Authority ruled the international waters beyond the 200 mile exclusive economic zones for the 193 member states to the United Nations.

Council seating arrangements were highly political and somewhat significant to decoding which countries were assigned certain areas of representation. "Tonga is now a member state to the International Seabed Authority council," said Lord Ma'afu telephoning from Tonga to update me in Auckland. I already knew: "You might be in the wrong group. Group D where Fiji is with Jamaica speaks for small island developing states. Tonga is in Group E with 18 countries to make up an even spread across regions." His retort was brusque: "It does not matter which group Tonga is put in. We are on the council. That is the important part."

But the five distinct groupings on the International Seabed Authority council did indicate an inventory of classifications assigned to various countries. Group D corresponded to "six members from among developing States Parties, representing special interests" of which "island States" was included (International Seabed Authority, 2014a). Clearly this was Fiji's positioning on a council that had international governing authority by law, and it did give the Fijian government an upper hand in being a delegated country to speak exclusively and unequivocally for the world's "island States" (International Seabed Authority, 2014a).

- Six members from among developing States Parties, representing special interests. The special 
interests to be represented shall include those of States with large populations, States which are land-locked or geographically disadvantaged, island States, States which are major importers of the categories of minerals to be derived from the Area, States which are potential producers for such minerals and least developed States. (International Seabed Authority, 2014a).

Tonga took a back seat in the fifth and final Group $\mathrm{E}$ which saw "eighteen members elected according to the principle of ensuring an equitable geographical distribution in the Council as a whole" (International Seabed Authority, 2014a). Located in the "36-member Council" on behalf of a "geographical region" Tonga symbolised the "Asia-Pacific," not singularly Oceania. (International Seabed Authority, 2014a, 2014b). By this, the "Asia-Pacific" region was dominated by Asian countries located on the continent, namely China, who doubled up as a state sponsor and exploration company of seabed minerals. By no means was this "geographical region" of the "Asia-Pacific" typified as water world, meaning the small island developing states cohabiting a Pacific Ocean that Tonga shared side-by-side with Fiji shouldering its eastern sea boundary. If the Tongan government thought it would be putting in the word specifically for Pacific "island States," it had another think coming (International Seabed Authority, 2014a).

- Eighteen members elected according to the principle of ensuring an equitable geographical distribution of seats in the Council as a whole, provided that each geographical region shall have at least one member elected under this subparagraph. For this purpose, the geographical regions shall be Africa, AsiaPacific, Eastern Europe, Latin America and the 


\section{Caribbean and Western Europe and Others. (International Seabed Authority, 2014a).}

From July 14th to the 25th of 2014, the International Seabed Authority assembly convened its twentieth session representing 165 member states as well as the European community, three economic organisations integrated into the European Union by the 2009 Treaty of Lisbon. Thursday July 24th saw the assembly's full day meeting paint some detail of the political seascape in respect of where Pacific Island states positioned themselves on exploiting seabed minerals as a national and regional development goal. Opinion was divided in two.

Kiribati and smaller island states of low-lying atolls losing their landmass to rising sea at a faster rate than raised coral atolls and volcanic islands were cautious and reserved. Given the gravity of their climate predicament, smaller island states considered development as sustaining physical environments and natural resources. Understandably, their politics aligned with the International Union for the Conservation of Nature (IUCN), Greenpeace International, and the Deep Sea Conservation Coalition (DSCC); all which were international environmental organisations in attendance as critical observers to the International Seabed Authority proceedings.

Tonga, by comparison, perched on the other side of the opinion divide. The Government of Tonga reported the Tongan delegation in attendance was "led by H. E. [His Excellency] $\mathrm{Mr}$ Mahe 'U. S. Tupouniua, Tonga's Permanent Representative and Ambassador to the United Nations in New York, Dr T. Suka Mangisi and Mr Taaniela Kula" [from the Ministry of Lands and Natural Resources] (Government of Tonga, 2014). Noted was a commendation from the Tongan state representatives nodding to "the partnership of its contractor Tonga Offshore Mining Ltd and its Director and Tonga 
Manager Mr Paula Taumoepeau, and Nautilus Mineral's Vice President for Strategic Development and Exploration $\mathrm{Mr}$ Jonathan Lowe, for the contribution and assistance they had provided during the [International Seabed Authority's twentieth] Session" (Government of Tonga, 2014).

Driving the Government of Tonga's development mission to consolidate seabed mineral exploitation as a sustainable economic growth sector was "the partnership [with] its contractor Tonga Offshore Mining Ltd," a Nuku'alofa based subsidiary company of the Canadian multinational Nautilus Minerals Incorporated (Government of Tonga, 2014). Focused on its state sponsorship of Nautilus Minerals' exploration licenses in the Clarion Clipperton fracture zone, an ocean area outside of Tonga's exclusive economic zone in international waters of the north Pacific, Tonga angled this commercial venture as the government model for doing business with private companies from wealthy developed nations.

Was Tonga winning on the commercial enterprise front? Undoubtedly, a high level of information dependency on Tonga Offshore Mining Limited, particularly the country director Paula Taumoepeau, fortified the relationship closeness and cosiness. It is here that I am urged to voice a fault-finding probe: Was the Tongan state exercising judicious business sense to craft its national seabed minerals trade on one experience with, and guidance received from, Nautilus Minerals Incorporated? Three additional companies to Nautilus were contracted by the Tongan government as the state sponsor (Brown Pulu, 2013a).

Why privilege Nautilus Minerals and take no notice of the others? Was it not wiser to amass information from extensive sources to draft national legislation and regulations on seabed minerals, specifically for protecting the state against liability for environmental loss and damage? Why put all the business eggs in the Nautilus basket? Nautilus, the company reliant on 
the Tongan state as a mainstay sponsor for seabed exploration and exploitation in the Pacific Ocean. Nautilus, whose Solwara project in partnership with the Papua New Guinea state collapsed from what local communities saw as one-sided financial benefits to the company measured against meagre royalties for the country.

Surveying the assembly's July 24th discussion, Vanuatu and the Cook Islands which were larger South Pacific states made up of raised atolls appeared quick off the mark to side with countries in favour of seabed exploitation. There was a catch decelerating the push to commercially exploit hydrothermal vents on the ocean floor for polymetallic nodules containing gold, silver, copper, manganese, nickel, cobalt and zinc. The International Seabed Authority had no work code systematising the legal obligations, technical regulations, and monitoring processes for exploitation. Adding pressure to this tight spot was the fact that small island developing states did not possess national legislation and technical regulations for deep sea mineral exploration and exploitation.

Without a seabed minerals act, how could the Tongan state protect itself from Nautilus Minerals Incorporated when it boiled down to liability for environmental damage to the ocean floor in international waters? In the South Pacific subregion, the larger island states stood apart from their smaller island Micronesian peers, with the Cook Islands articulating they wanted the International Seabed Authority to devise an "exploitation code" pronto. Exploitation "would lead us all" not into temptation but "into the next exciting phase of the work," so they assumed (ISA Press Release, 2014c, p. 2).

Cuba, Italy, Spain and Vanuatu all shared the view that developing the regulations for the exploitation of deep seabed minerals should be a priority task on the Authority's agenda. Cook Islands said the exploitation 
code would "lead us all into the next exciting phase of the work of the Authority." (ISA Press Release, 2014c, p. 2).

Kiribati slammed on the brakes, requesting the International Seabed Authority to prioritise "the speedy implementation of [an] environmental management plan" (ISA Press Release, 2014c, p. 2). In particular, they honed in on "the Clarion-Clipperton Fracture Zone" where the majority of seabed licenses had been issued for exploration in the Pacific Ocean's international waters (ISA Press Release, 2014c, p. 2). Perceptibly, Kiribati's close proximity to the zone, compounded by President Anote Tong's conviction his entire country would be climate refugees in fifty years' time, presented double cause for concern.

Members cited the protection of the marine environment as an ongoing priority for the Authority. Kiribati called for the speedy implementation of [an] environmental management plan in the ClarionClipperton Fracture Zone. (ISA Press Release, 2014c, p. 2).

The influential environmental organisations on the world stage took the stand as observers to the International Seabed Authority's twentieth assembly, dividing up the labour into three arguments laid out on the discussion table. Up first was the International Union for the Conservation of Nature (IUCN), whose Oceania programme was the organisation's largest to be regionally funded and operated by staff based in Suva, Fiji. Their argument forthrightly backed Kiribati. Primarily, the "environmental management plans" had to be instated and operable for areas subject to "exploration activities" such as 
the north Pacific's "Clarion-Clipperton Fracture Zone" (ISA Press Release, 2014c, pp. 2-3).

The International Union for [the] Conservation of Nature (IUCN) aligned itself with those delegations [such as Kiribati] which called for the development of environmental management plans in areas where exploration activities were taking place. (ISA Press Release, 2014c, p. 3).

Second was a bone of seabed contention addressed by Greenpeace International. Liability for environmental "damage occurring as a result of seabed mining" and the "disposal of waste at sea" must be written into "international law and regulation" (ISA Press Release, 2014c, p. 4). In turn, this would be forcible on sponsoring states and the rationale by which they crafted their national legislation and seabed mining regulations.

The Greenpeace International representative pointed to two gaps in international law and regulation which had to be filled by the time the exploitation regulations were in place. The first was the issue of liability and redress in relation to damage occurring as a result of seabed mining. The other gap to be addressed was the issue of disposal of waste at sea. (ISA Press Release, 2014c, p. 4).

Third was perhaps the complicated argument to apply to Pacific Island states. I emphasise intricacy because the physicality and geography of Pacific Island states resembles large ocean territories with overlapping and contested exclusive economic zones, and competing continental shelf claims. The Deep Sea Conservation Coalition brought up the 
organisation's core business, "governing deep sea fisheries" (ISA Press Release, 2014c). Complexly, the reality was the international administration of deep sea fisheries and minerals crossed-over into one another's management of natural resources extracted from the world's oceans and seas. The tricky part was how to coordinate the two systems of standardising and regulating the different natural resources, minerals and fish, so they did not collide and cancel each other out.

Deep Sea Conservation Coalition pointed out that global consensus had already been achieved on a number of measures governing deep sea fisheries, which might be relevant to the management of deep seabed mining. The representative said that one of the overarching objectives of establishing international standards on the management of activities in the seabed must the avoidance of damage to the ecosystem. He added that the Authority should aim at consistency with other regulatory bodies. (ISA Press Release, 2014c, p. 4).

Fisheries was the Pacific Island states' development industry that turned Lord Ma'afu uneasy. He wanted to balance his familiarity of seabed minerals with sea cucumber, making an educated guess that fisheries activists whether coastal or deep sea, could band together if they felt the fledgling deep sea mining business threatened ecosystems on which their established sectors generated livelihoods and food supplies for Pacific Islander fishermen and coastal communities. There were urgent questions to which Tonga's Minister for Lands and Natural Resources sought answers. 


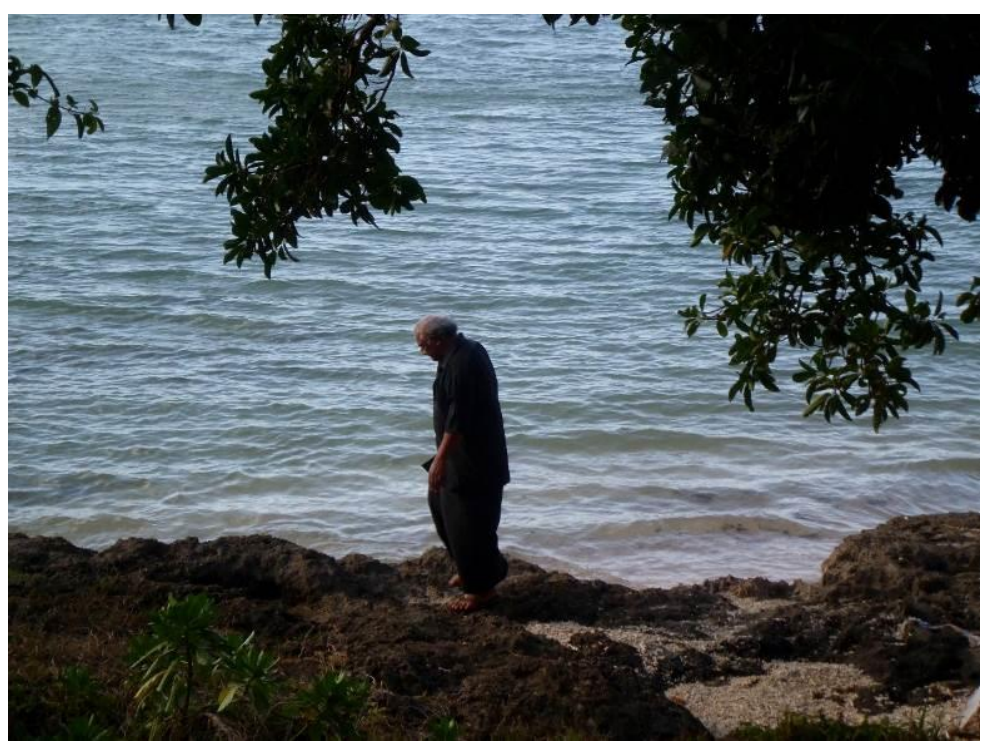

Lord Nuku of Kolonga who is the nobles' representative for 'Eua walking the foreshore fronting his coastal village in Tonga's eastern district. Lord Nuku and Kolonga people currently applying to the Minister for Fisheries to become a designated special management area under the Fisheries Management Act 2002, granting the village community rights to sustainably manage a 2.4 mile long foreshore to conserve inshore fisheries. Photograph by Teena Brown Pulu, 2013.

Vitally, what unresolved arguments had the potential to thwart Tonga's seabed minerals trade from travelling full steam ahead into the exploitation of polymetallic nodules for commercial sale? Subsequent to this where, concisely, did tensions arise from practicing these two development industries, fisheries and seabed minerals? Hence, Ma'afu and his queries arrived at the Pacific Beche-de-mer and the Future of Coastal Fisheries Meeting in Nadi, Fiji from August 6th to the 8th 2014 as the Tongan Prime Minister's special envoy and 
stand-in for the Minister for Agriculture, Food, Forests and Fisheries, Sangster Saulala.

Day one of the three-day talkfest saw Moses Amos of the Secretariat of the Pacific Community set the sobering mood and tone. Painting the bleakest future for the survival of inshore fisheries stock in coastal communities of Pacific Island states and territories, Amos hinted at extinction in graphic terms. Leading a panel discussion at the Pacific Beche-de-mer and the Future of Coastal Fisheries Meeting on August 6th 2014, he predicted what was yet to come as "leading to a perfect storm" (IUCN, 2014c).

Overfishing, population growth, rapid urbanization, habitat degradation and climate change are all leading to a 'perfect storm' for coastal fisheries in the Pacific Islands region, which means that many Pacific Island countries and territories will need to find alternative sources of protein for their population within the next two decades. This sombre reality was presented to the Pacific Beche-de-mer and the Future of Coastal Fisheries Meeting in Nadi, Fiji, this morning by $\mathrm{Mr}$ Moses Amos, Director of Fisheries, Aquaculture and Marine Ecosystems (FAME) division at the Secretariat of the Pacific Community (SPC). (IUCN, 2014c).

At a glance, it looked rich that Ma'afu who had metamorphosed from a climate campaigner to the seabed minerals minister was in attendance for the Tongan state at a regional sea cucumber and coastal fisheries forum organised by conservationists, namely the International Union of the Conservation of Nature (Ministry of Environment and Communications, 2014). Tonga, however, had no option but to front up as a co-host country together with Fiji and the Republic of the Marshall Islands. 
Fiji's capital Suva provided a hub for the regional polity organisations, the Pacific Islands Forum Secretariat and the Secretariat of the Pacific Community. Suva, Fiji was also the non-government organisation base for the Oceania office of the International Union for the Conservation of Nature, and various environmental advocacy groups concerned with the ocean and coastal protection of species and ecosystems. By comparison, the Marshall Islands was a smaller island state advocate for sustainable fisheries at coastal community and deep sea levels of activity.

Thrown in the mix was Tonga, who seemed oddly placed among the big hitters of Pacific Island states; small island developing states that showed backbone when it came to affirming fisheries conservation as significant to their population's survival. To be brutally honest, Tonga had no stand-alone fisheries ministry or department, and nor was it likely to get one under the Tu'ivakano administration. Fisheries was a small division of a ministry that conflated agriculture, food, forests, and fisheries into a single government agency for farmers and fishermen alike. Unrealistically, the Tongan state assumed the work methods and environments of the two sectors were similar enough to be managed under one roof, which was simply not true in practice. In the end, agriculture took priority in preferment and funding, and fisheries by contrast dwindled.

Politically, the nitty-gritty talk at the Beche-de-mer and the Future of Coastal Fisheries Meeting conveyed double-edged action. First, the sole emphasis on sea cucumber and inshore fisheries of coastal communities in Pacific Island states was a deliberate strategy. Shifting ministerial dialogue away from the commercial industry of tuna and deep sea fishing, it refocused on managing sustainable food supplies for villages and outer islands. 
On the regional table was the toil and trouble of everyday life; the difficulty of feeding households and communities by foraging, gathering, and diving for seafood in reefs, lagoons, and foreshores. The lived reality was that village shores and beaches no longer supported the high level of use and extraction of fish, shellfish, molluscs, and crustaceans.

Shifting to sustainable management of these resources will be the main topic of discussion at the Pacific Beche-de-mer and the Future of Coastal Fisheries Meeting in Nadi, Fiji, from 6 to 8 August 2014. The meeting of fisheries ministers is being co-hosted by the Governments of Fiji, Tonga and the Republic of the Marshall Islands. It aims to build collective will in the region to start managing these resources appropriately, so that they remain available for future generations. (IUCN, 2014d).

Second was a call to action communique released at the meeting's conclusion by seven government ministers representing the Pacific Island states of Fiji, Tonga, the Marshall Islands, Samoa, the Cook Islands, Vanuatu, and Papua New Guinea. Set out in the co-signed document were recommendations on the advice of key representatives from the International Union of the Conservation for the Nature, the Secretariat of the Pacific Community, as well as consultants and government officials from fisheries ministries.

The seven ministers' endorsements were organised around pushing on the regional front for Pacific Island states to adopt a synchronised tactic for systematically managing coastal fisheries, particularly beche-de-mer as a commercial income earner. And here lay the riddle of commercial versus community resource management. 
By one mode of operation, the "regional initiative" put forward was oriented in improving the product quality, the supply chain value to the Asian market, and cash returns to Pacific Island states for beche-de-mer (IUCN, 2014a). Succinctly, sea cucumber was a sustainable profit-making export producing millions of dollars for poor local economies. Unambiguously, this was commercial resource management of sea cucumber targeted for Asian buyers.

A regional initiative that helps achieve sustainable management of beche-de-mer resources will be investigated, with willing countries working together to share information and data on buyers and identify market mechanisms to improve the value of the product to Pacific Island countries. (IUCN, 2014a).

By a different method altogether the director of the International Union for the Conservation of Nature Oceania office, Taholo Kami, described the Pacific Beche-de-mer and the Future of Coastal Fisheries Meeting as linked to the promotion of "locally managed marine areas" (Coutts, 2014b). Ambiguity blurred the coastal fisheries agenda.

Tonga's Fisheries Management Act 2002 referred to "locally managed marine areas" as special management areas (Coutts, 2014b). Effectively, these were designated foreshores fronting villages and outer island settlements which coastal communities harvested daily for subsistence seafood. Under the Fisheries Management Act 2002, coastal communities in Tonga could lodge a formal application to the Minister for Fisheries to control and manage the inshore fisheries of their allocated foreshore area.

Confusingly, two political memos emerged from dialogue exchanged at the Pacific Beche-de-mer and the Future of Coastal Fisheries Meeting. Commercial management of beche- 
de-mer as a lucrative export regulated by government fisheries regimes on cultivation, harvesting, and export sale was one case. In some ways, however, it was a commercial development strategy contradicted by Kami's remarks. "Locally managed marine areas" presented practicable and workable systems of coastal fisheries management that could be increased throughout Pacific Island states, suggested the International Union for the Conservation of Nature director (Coutts, 2014b).

Like I said locally managed marine areas, I think there's over two thousand in the Pacific; it started here in Fiji and the Solomons, Micronesia. These are when a village chief says look, for this one square kilometre it's important for the recovery of the species or the ecosystem that there is a no-take, and declares a notake for several years and the village people respect that. And they're finding in Samoa and in other countries where they're monitoring them that it's actually improved the fishery around the no-take zone. And completely managed with technical help from fisheries departments, from NGOs, and others the villagers have been able to see some recovery of species and they've seen some impact in things like size of fish. (Taholo Kami cited in Coutts, 2014b).

Kami threw out the catchphrase "political will for action" in the convoluted midst of conflicting standpoints (Coutts, 2014b). Had the Pacific Beche-de-mer and the Future of Coastal Fisheries Meeting petitioned Pacific Island states to step up the commercial quality and supply of beche-de-mer, or expand the number of "locally managed marine areas?" (Coutts, 2014b). If tightening up government regulation of beche-de-mer harvesting and export sales clashed with 
loosening up coastal areas for community management, then how would the two methods of coastal fisheries sustainable management be settled? In short, who knows?

I think it's an issue, in this one I hope we start to get more to raise the bar in terms of political will for action. I think there are clear answers, and it's the whole thing of zoning, starting to recognise what [are] the critical areas for spawning, and what are the controls and management that needs to be put in; what needs to be no-take versus managed, better managed fishery areas; how do we bring communities on board effectively. And we've got good examples of what works right throughout the Pacific. And the issue becomes how do we this better, and in some cases it's not just these little declarations but also government stepping in and saying there's some offshore areas, and bigger areas that need to be better managed. (Taholo Kami cited in Coutts, 2014b).

To trace back to Ma'afu's anxiety that coastal and deep sea fisheries might, if left up in the air, crash head-on into seabed mineral exploitation, Kami outlined the contours of where the debate was headed. "It's the whole thing of zoning," he impressed (Coutts, 2014b). "Better managed fisheries areas" worked on two counts (Coutts, 2014b). Bringing "the communities on board" to self-govern their own coastal fisheries was the first policy, and the second involved Pacific Island governments assigning "offshore areas, and bigger [deep sea] areas that need to be better managed" (Coutts, 2014b).

The "whole thing of zoning" intersected with Ma'afu's ministerial authority over lands and natural resources to direct the seabed mineral industry from exploration and identifying potential polymetallic excavation sites into full- 
scale exploitation for commercial sale (Coutts, 2014b). If the Tongan state selected ocean spaces within its exclusive economic zone to be managed exclusively as conservation areas for migratory species such as tuna, then deep sea fisheries zoning would indeed limit and contest the area size set aside for seabed mineral activity.

Was there a United Nations convention governing the protection of migratory species in national and international waters? The concise answer was yes. The Convention on the Conservation of Migratory Species of Wild Animals 1983 was the United Nations Environment Programme (UNEP) authorising body of which Tonga was classified as a non-party range state.

By this, the Tongan state had yet to give its assent to ratify the convention, which in turn, would make it a fully-fledged party state. Notably, a conference of parties' workshop for the Pacific region was held in Nadi, Fiji from the 18th to the 20th August 2014 to consider the United Nations draft strategic plan for migratory species to be put in place from 2015 to 2023.

One thing was certain in the middle of hazy fisheries policymaking. Collectively, if Pacific Island states steered a regional plan convincing countries to designate national "offshore areas" specifically for fisheries management, Ma'afu would be compelled to go into bat for his ministry. As the Minister for Lands and Natural Resources, he would be held responsible for laying down the set of circumstances in which zoning overlapped with, and conceivably constricted, the development of Tonga's seabed minerals industry.

\section{Source of regional instability}

"No, leave the constitution alone. The last thing we want is for every government that comes in here to be changing the constitution. How many years have we had this constitution?" 
"A hundred and thirty nine years." I answered the question Ma'afu put to me literally, although it was not a matter-of-fact inquisition. He was making a point, rather than plainly soliciting a correct response.

Gesturing to a popular belief that the durability of Tonga's 1875 constitution had provided the cornerstone of peace and stability, he scorned at how since the 2010 reform, statutory amendments knocked the country and citizens off-balance. Ma'afu regretted that in four short years, changes to the political system produced an opposite effect. In actual fact, reform struck dissolutely at Tonga's modern foundation. The perpetuity of the monarch and the ruling class captured in a 19th century constitution that had endured, undisrupted, for well over a century, characterised Tonga as Tongan citizens understood it.

His sentiments had academic backing. Ian Campbell, a Pakeha New Zealander and history professor wrote that despite Tonga being predominantly viewed by outsiders, Westerners in particular, as "an anomaly in the world" because it was a constitutional monarchy where the King retained executive powers, "by no means [was it] self-evident that this constitution is inappropriate" (Campbell, 2004, p. 335).

Campbell's argument went further to problematise Western notions that "democracy and republicanism" naturally engendered development and progress (Campbell, 2004, p. 335). There was nothing natural about this political ideology; it was completely manufactured and imposed on developing countries by global forces of power. If anything, the Tongan example of a monarch who "exercises significant authority" according to a 19th century constitution proved this worldwide belief to be quite mistaken (Campbell, 2004, p. 335). 
It is, however, by no means self-evident that this constitution is inappropriate, and a strong argument can be made that the quality of life enjoyed by Tongans under this constitution is superior, by conventional indicators, to that of most other Pacific Islanders and other 'third world' populations. (Campbell, 2004, $p$. 335).

If the "quality of life enjoyed by Tongans under this [1875] constitution [was by any means] superior" to other Pacific Island states, then arguably the Land Act 1988 buttressed the general wellbeing of citizens linked to a country's standard of living (Campbell, 2004, p. 335). As I have written elsewhere, the conventional wisdom widely held by Tongans, especially the nobility who constituted the landed gentry, was that the Native land tenure system in which land could not be bought or sold, but rather, leased from government and estateholders, prohibited land privatisation and outright sales to non-Tongans (Brown Pulu, 2011, 2014b). Principles governing Native land tenure outlined in the constitution made it plain as day that by no means whatsoever was land to be sold outright because, "All the land is the property of the King and he may at pleasure grant to the nobles and titular chiefs or matabules [matapule, titled orator or minor chief] one or more estates to become their hereditary estate" (Kingdom of Tonga, 1988b, p. 30).

It is hereby declared by this Constitution that it shall not be lawful for anyone at any time hereafter whether he be the King or any one of the chiefs or the people of this country to sell any land whatever in the Kingdom of Tonga but they may lease it only in accordance with this Constitution and mortgage it in accordance with the Land Act. And this declaration 
become a covenant binding on the King and the chiefs of this Kingdom for themselves and their heirs and successors for ever. (Kingdom of Tonga, 1988b, p. 30).

Keeping foreigners at bay by preventing them from purchasing land, or worse than that, owning more land than the locals was looked upon as constitutionally upholding Tongan morality and integrity. Tongans who had migrated and resettled overseas, however, hinted at land reform with stauncher conviction than Tongans living in the homeland state remarked on. Principally, their idea was to restructure land tenure to stop the nobility collecting millions of dollars from commercial leases (Brown Pulu, 2014b).

Melino Maka, chair of the Tonga Advisory Council in Auckland, New Zealand held a firm opinion on the matter. Maka argued that "land of national interest" such as Fua'amotu International Airport which raised considerable rent paid-out to the noble and estate-holder Kalaniuvalu, should go back to the Government of Tonga "to keep the airport costs down for the public" (Brown Pulu, 2014b, p. 141). "Land of national interest," by his decree, "should benefit" the Tongan public "not the noble" (Brown Pulu, 2014b, p. 141).

Land of national interest has to be brought up to inform the people. The nobles, the amount of money Kalaniuvalu received from government for the airport lease at Fua'amotu. Rent made by the noble should go back to the government to keep the airport costs down for the public. The public should benefit from land of national interest, not the noble living in luxury. (Melino Maka cited in Brown Pulu, 2014b, p. 141). 
Sefita Hao'uli, Tongan veteran broadcaster in Auckland, New Zealand explained the adjoining part linked to Melino Maka's rationale. Conventionally, the nobility's role in the social hierarchy was to allocate land allotments equitably to commoners living on their estates. If the traditional ruling class could no longer fulfil their duty of fairly and prudently redistributing land to their people first and foremost, then they served little purpose in Tongan society (Brown Pulu, 2014b, p. 141).

Land has become a problematic area for Tongans. Tupou $V$ gathered opinion through the Land Commission report. People are scrambling for land but the point is, land is of no use to the nobles if nobody likes the nobles. If land can't be dealt with fairly by rules for the benefit of all then the nobles do not have a role. Effectively, they have made themselves redundant. (Sefita Hao'uli cited in Brown Pulu, 2014b, p. 141).

For Ma'afu, his deep-seated apprehension pointed to a zealous undercurrent brimming below the surface of Tongan political life. Categorically it could be read that his military education was the method he used to scrutinise the confusion Tonga was experiencing by tweaking the constitution under the impression of making improvements. The unrest he sensed was national security, a strategic interpretation of how dishevel inside the state could, if left unchecked, exacerbate ongoing political unpredictability to the radical edge where Tonga became "a source of regional instability" (Campbell, 2004, p. 335).

In Tonga, citizens were exceptionally proud of the longevity and fortitude of their 1875 constitution. They also found unity in their shared history of an ancient Tongan civilisation 
structured by dynastic rulers, chiefs, and clans. Together, Tonga's constitution and ancient civilization produced the social glue of national identity. Accordingly, it was beyond an ordinary Tongan's understanding that domestic politics were hinging on the extreme, crazed with a taste for subverting and weakening state and society. Unravelling this contentious point, Ian Campbell penned it concisely.

[The] perception of Tonga as politically and socially archaic [is commonplace], and that as such it is likely sooner or later to experience the pangs, not to say upheavals, of a lurch into the modern world in circumstances that could make it a source of regional instability. If 'security' is an issue for the Pacific Islands, it concerns this question of internal disorder having a capacity to infect the internal affairs of neighbouring countries, an interpretation which has some limited empirical support. (Campbell, 2004, p. 335).

Considering the "question of internal disorder having a capacity to infect the internal affairs of neighbouring countries," was Tonga a basket case? (Campbell, 2004, p. 335). A leading theory framed Fiji not Tonga as the culprit whose "internal disorder" threatened to contaminate the South Pacific's trouble spots by influencing domestic politics inside fragile states. Did Tonga now eclipse Fiji?

By this, a political tug-o-war emerged between commoner and noble politicians as to whether further constitutional reform was necessary. Democratic Party parliamentarians contended the political system had to correlate with what the people wanted, which was to completely abolish the nine nobles' representative seats, or downsize them to three seats in the legislature elected by registered voters on the general 
roll; not that the majority of Tongan voters supported 'Akilisi Pohiva's leadership and party politics.

Sione Taione, the people's representative for Tongatapu constituency number 8 pushed to amplify constitutional reform. The evening of Tuesday 19th August 2014 saw Taione's private member's bill enter the House. He vied to amend the constitution by pruning back the nobles' privileges. Taione wanted people's representatives to parliament, not singly nobles' representatives, to be eligible for the roles of Speaker of the House and the Deputy Speaker of the House; positions that historically were set aside exclusively for the nobility (Radio Tonga, 2014; Tonga Hansard, 2014a). The question, therefore, was had the tussle to win control over political uncertainty caused a deadlock that delivered no real solution for moving forward?

Different to the Feleti Sevele government of 2006 to 2010, the Tu'ivakano regime in office from December 2010 to November 2014 exerted a deliberate clampdown on snipping and clipping the constitution. The Prime Minister Lord Tu'ivakano and the Minister for Lands and Natural Resources Lord Ma'afu had served in Sevele's cabinet. They were curtly aware that rushing significant legislation changes through the House in a mad dash before the cut-off date could potentially do more harm in the long run than good.

Being nobles' representatives to parliament, Tu'ivakano and Ma'afu were strongly inclined to preserve the nineteenth century liberal principles engraved in the 1875 constitution and duplicated in the Land Act. Primarily, the statute on land law guaranteed their landed gentry privilege to inherit titles and estates as noblemen, and to bequeath the class privilege of male birth right and inherited land holdings to their eldest sons. 
Any land granted as an hereditary estate shall descend to the lawful heirs of the body of the grantee. ...Upon the death of a holder of an hereditary estate ... His Majesty shall cause the name of the lawful successor to the title to be published in the Gazette together with the date of his succession. (Kingdom of Tonga 1988c, pp. 20, 23).

The constitution's 19th century codes reflected Christian morality of the time, which is still practiced by the majority of church-going Tongans today. In context, a noble's illegitimate offspring were precluded from inheriting title and land by paternity. As the constitution prescribed, the eldest son produced from a noble's first legal marriage (as the landed gentry were permitted to divorce in a court of law) became automatically eligible for hereditary birth right.

The following is the law of succession to hereditary estates and titles:

Children lawfully born in wedlock only may inherit and the eldest male child shall succeed and the heirs of his body but if he have no descendants then the second male child and the heirs of his body and so on until all the male line is ended. (Kingdom of Tonga, 1988b, pp. 31-32).

What is more, the monarch's pivotal position in the constitutional arrangement to hold and exercise executive power was fundamental to Tonga continuing to function as a South Pacific Kingdom in the 21st century. To be concise, preservation was about maintaining a constitutional monarchy that upheld Tonga's political structure. Affirming the traditional ruling class and the commoners would both be represented in parliament, and that the nobles' privileges 
warranted in the Act of Constitution of Tonga coupled with the Land Act remained intact, were central to a constitutional monarchy's meaning and purpose.

The current government policy steered clear of Sevele's gung-ho approach. When it came to another round of reworking the constitution, their motto was to make haste slowly. Irony was at play. Prime Minister Lord Tu'ivakano and his eleven ministers found that during their four-year term, they were to submit to the legislature a trail of constitutional rectifications to the 2010 amendments to the Act of Constitution of Tonga: 1988 Revised Edition, which the Sevele government before them had ratified. Put simply, the Government of Tonga ended up correcting the corrections to the constitution which the former government had brought about.

To explain the background fertilising a baffling situation the Tu'ivakano cabinet faced in parliament, under pressure to make political reform happen in a limited timeframe, the former Prime Minister Sevele railroaded through hasty alterations to Tonga's constitution during the parliamentary session of 2010. In total, forty eight bills passed into legislation in the four months parliament sat, and it was rumoured that some of the bills explicitly to do with political reform were not discussed by the Whole House Committee representing the legislative assembly. Of the three amendment acts to the Act of Constitution of Tonga: 1988 Revised Edition, it was the third sanctioned into law by King George Tupou V on September 24th 2010 that instigated internal and external reviews carried out from 2012 to 2014 on "the practical operation of the reforms" in relation to the judiciary (Tonga Daily News, 2014b).

The story unfolded that in 2012, the Tu'ivakano cabinet requested the Ministry of Justice to "report on the new judicial system" reorganised under the Sevele administration's 2010 
constitutional amendments (Tonga Daily News, 2014b). The ministry's "report identified flaws," but the external report was far worse (Tonga Daily News, 2014b). "The present Constitution of Tonga can lay claim to being the most poorly structured and drafted Constitution of any Country in the Commonwealth," wrote constitutional law consultant Peter Pursglove (Moala, 2014). He had been recommended as the man for the job. Tonga approached the Commonwealth organisation of 53 member states who were once politically affiliated to the colonial British Empire, of which 31 were small island developing states. Asking the Commonwealth for assistance on the matter, they got Pursglove.

Superior to any recommendations the Ministry of Justice had given to cabinet; almightier than any views expressed by Tonga's law practitioners working inside the homeland state; was Pursglove's review. He was the trigger for action, obliging the Government of Tonga to amend what was depicted as a dodgy constitution authorising a lop-sided judiciary. My point is the all-knowing power and persuasion of international relations fashioned the Tongan bureaucracy over and above the influence of national politics, internal relations, and public opinion. What Tongan citizens thought of their own country and government was truly peripheral. The verdict taken seriously was the outside world's judgement of Tonga.

According to Pursglove, Western notions that the modern state's three branches of authority, the legislature, national executive, and judiciary functioned independently from one another, but at the same time, were transparent and accountable to each other's operation as an interconnected system of governing power, did not happen in Tonga. A post 2010 judiciary had splintered into three unfeasible and contradictory parts, in addition to the Ministry of Justice.

In short, the Sevele government's 2010 constitutional reform line-up instated a judiciary in triplicate. First, there 
was a Lord Chancellor's Office; second, an Attorney General's Office; and third, a Judicial Appointments and Discipline Panel (JADP) of Law Lords who doubled up as the King's Privy Council. Troubling for a revised constitution that allegedly moved towards democratising the state's principles and processes was that the Lord Chancellor and the Attorney General "answer only to the King in Privy Council" (Moala, 2014). Democracy was amiss if indeed it had been taken to mean a representative system of government where citizens of the state exercise power and decision making by electing individuals to parliament to stand, act, and speak for their interests.

While the Ministry of Justice remains accountable to the people through Parliament, the Office of the Lord Chancellor and the Office of the Attorney General are not publicly accountable and answer only to the King in Privy Council. This is contrary to the democratic principles upon which the new constitution was founded. (Peter Pursglove cited in Moala, 2014).

At a glance, the Sevele administration's judiciary resembled autocracy exemplified by the ruling monarch's executive power to appoint, control, and dismiss the Lord Chancellor, the Attorney General, and the Judicial Appointments and Discipline Panel (JADP). Not to mention, there was the question of Law Lords constituting the Privy Council. The Law Lords were not supposed to interfere in state governance carried out by the national executive, but they did assume the role of advising the monarch on whether to approve or refuse bills passed by parliament as statutes. Could that be construed as stepping on governance territory, or was it part-and-parcel of the King's executive power as sovereign and head of state? Tonga's nonpartisan and self- 
regulating judiciary looked curiously like a dependent ward of the reigning monarch.

Remedying the judiciary's complicated operation got increasingly convoluted when in late August of 2014, Clive Edwards, the Minister for Justice submitted his amendments to the House in two bills. Lord Nuku, in collaboration with Lord Tu'iha'ateiho and Lord Tu'ilakepa, led the vote against the justice minister's corrections to the 2010 constitutional alterations completed by the Sevele government. Upended, the bills returned to the Tu'ivakano cabinet for additional work (Fonua, 2014). Time was running short, and a familiar situation looked to unfold. Parallel to the Sevele regime's tight spot, the annual parliamentary session would be flooded with bills pouring into a House of fatigued parliamentarians doing overtime. Sitting ceaselessly through readings one after the other that pressed into evening, a risky edge drew near. Could a few proposed laws fall off a cliff to become hurried legislation in which four years from now, no one recalled discussing their critical points of law?

From the furore a remarkable judgement came from Pursglove's criticism of the monarch's executive power over Tonga's newly devised justice system, the only one of its kind in the Commonwealth. As a result it was uttered among Tongan writers, critics, and political analysts that the reason why the conservative corner of the establishment withheld from shooting the messenger and burying his report, so to figuratively speak, was because the bearer of bad news was a foreigner (Brown Pulu, 2011).

Pursglove had outsider privilege by virtue of not being Tongan. For if he was an insider, he would definitely think twice about his survival odds as a local researcher working in a small island Kingdom policed by class and culture; a closed, insular, hierarchical, patriarchal, Christianised society where 
Voltaire's adage rang loud and clear: "Qui plume a, guerre a. To hold a pen is to be at war" (Voltaire, 1748).

Long-standing Tongan journalist Kalafi Moala quizzed, "who was really responsible for" restructuring the judiciary? (Moala, 2014a). There was no doubt the constitutional modifications legislated in 2010 under the Feleti Sevele government gave birth to the new justice arrangement. But whose brainchild was it to redesign the system? Who actually gave the order to go full-steam ahead? Furthermore, why was there no state record of public consultation and parliamentary debate on the acts to amend the Act of Constitution of Tonga: 1988 Revised Edition with explicit reference to the judiciary's makeover?

As expected of a Tongan analysis, Kalafi Moala stopped short of prying whether the late King George Tupou V was an accomplice to "ordering the sweeping changes" (Moala, 2014a), in stark contrast to Pesi Fonua stating the judiciary system "was a creation of the late" monarch (Fonua, 2014). But Moala sensed not to go there. If he was non-Tongan, he might feel uninhibited to grill the establishment for answers. As a Tongan national living and working in the homeland state, he understood too well that interrogating power and authority can lend to the wisdom that some stones are better left unturned. Quite simply because, by Voltaire's estimation, “to learn who rules over you, simply find out who you are not allowed to criticize."

As Tonga's Legislature work[s] to reverse legislations relating to the Judiciary as in the 2010 Constitution, the question remains who was really responsible for ordering the sweeping changes to the judicial sector, and why were the changes carried out without public discussion or debated in the Legislature. (Moala, 2014a). 
Woven in Moala's questioning was Tongan nostalgia for the past. "To reverse legislations relating to the Judiciary" formed the government and parliament's urgent business in the House, remarked Moala (Moala, 2014a). Recoiling back to pre2010, prior to the constitution being altered, before the political reform when Tonga "had a well-functioning Judiciary" prized by its citizens, and respected by outside observers, was the golden age he hinted at (Moala, 2014a). That was the era of constitutional stability and strength which Pursglove noted, adding weight to local lamenting for what went before, and what Tonga needed to go back to now.

Before the Constitutional reforms of 2010 'the Kingdom of Tonga had a well-functioning Judiciary that was independent and operated in accordance with recognized Constitutional Law standards.' (Peter Pursglove cited in Moala, 2014a).

To reiterate my position, it was a foreigner, an outsider, a non-TOngan constitutional law researcher named Peter Pursglove who impressed upon the nation that it "is truly a very sad state of affairs in the Kingdom that has one of the world's oldest surviving constitutions" for the Tonga to have slid backwards (Moala, 2014a). Unknowingly he echoed and evoked sentiments that the nobility in power, Prime Minister Lord Tu'ivakano and Minister for Lands and Natural Resources Lord Ma'afu, had sensed and said all along.

Tu'ivakano and Ma'afu had ministerial experience in two consecutive governments. They were able to reflect that in two terms amounting to eight years, it was "truly a very sad state of affairs" to witness Tongan state and society dismantle the country's stability that they, themselves, had engineered over one hundred and thirty nine years (Moala, 2014a). Tonga 
partly divorced culture and custom for what, precisely? The country hinged on an uncertain future created by others, Western states mainly, perceived to be more powerful, desirable, and knowledgeable in worldly affairs. On second thoughts, had converting from the old system to the new been completely advantageous?

When one considers the justifiable pride felt by Tongans everywhere in the First Constitution handed down by King George Tupou I in 1875, this is truly a very sad state of affairs in the Kingdom that has one of the world's oldest surviving constitutions. (Peter Pursglove cited in Moala, 2014a).

\section{Ambivalence of nobles in power}

Malakai Koloamatangi, a Tongan political scientist based at Massey University's Albany campus in Auckland, New Zealand announced to Radio Australia's Bruce Hill that "we've come a long way in fact since 2010 and even before then, when political reform was first talked of" (Hill, 2014). Perceptibly, his Auckland location outside of Tonga would have considerable bearing on his views which were, by comparison to Tongan commentators living in the homeland state, uncritically optimistic that democracy had been indisputably "accepted" across society and "institutionalised" in the state structure (Hill, 2014).

Without a doubt, the democracy conceived of and calculated by the Sevele government had been stylised to fit with, as opposed to undermine, the existing political assembly where the nine nobles' representatives seats were taken to be a permanent characteristic of the Tongan parliament. Kalafi Moala reasoned this by writing the Sevele regime figured "a 
more democratic structure" need not do away with "the basic fabric of Tongan social structure" (Moala, 2008, p. 184).

The [Sevele] government seems to be seizing the initiative for reform. They have indicated quite bluntly that reform is inevitable, and that they are working to reconstruct Tonga politically and economically to reflect a more democratic structure, without necessarily tearing up the basic fabric of Tongan social structure. (Moala, 2008, p. 184).

Nevertheless, it was a sore point that turned into a reoccurring strain in the human psyche of Malakai Koloamatangi, alongside Kalafi Moala and Tongan political analysts slanting towards the pro-democracy movement. Collectively, they identified nobles' representatives in the legislature, and the nobility at the government helm, as an uncalculated risk which had to be contained and controlled. By uncalculated, I mean that full consideration of what might result in continuing to have governments led by a noble premier with nobles occupying senior ministerial portfolios had yet to be weighed up thoroughly by commoner politicians and voters.

Corresponding with this line of thinking, the landed gentry in power signified where the Tongan model of democracy came unstuck, and why the peoples' representatives would need to correct the course of democratic evolution. In 2008, Kalafi Moala authored an essay titled Media and Conflict in the Kingdom where he argued "it is only a matter of time until elected officials will be running the government" (Moala, 2008, p. 184).

The issue now is no longer whether there is going to be reform, but that reform is taking place right now, 
and it is only a matter of time until elected officials will be running the government, making government in Tonga finally accountable to the people while retaining the uniqueness of our culture and social structure. (Moala, 2008, p. 184).

Anticipating the 2010 general election would bring about a government led by people's representatives, Moala made an assumption that accountability "to the people" simply meant being elected to parliament by Tongan voters (Moala, 2008, p. 184). The naïve logic that winning a constituency vote naturally produced an answerable politician was not true by any democratic country's standards. If there was a case in point, then the Democratic Party's four year term in the House as the Tu'ivakano government's opposition proved that the political behaviour of elected commoners was evidently disagreeable, compared to the nobility chosen by their class peers who consistently voted as a unanimous bloc on bills and decisions in the legislature.

The original twelve seats in the House won by the Democratic Party produced politicians first, and party members second, who as a voting bloc were answerable to no one. For a left-wing organisation inclining towards socialism, the Democrats lacked party discipline. Defecting parliamentarians crossed the floor to government, either holding on to their Democratic Party affiliation, or abandoning the party altogether to become an independent member. This was compounded by private member's bills tabled by various representatives for constitutional changes that were not consulted on, or agreed to by their constituents. Contritely, a string of bills entering the House revealed a public staging of individual self-interest, political ego, and unabashed selfpromotion. 
The break-up of the Democratic Party into two splinter groups of candidates standing for election, one led by 'Akilisi Pohiva and the other by Pohiva's former deputy 'Isileli Pulu, troubled Malakai Koloamatangi. "It doesn't give a very good picture of democrats cooperating," he confessed to Bruce Hill of Radio Australia (Hill, 2014a). Entrenched was a chronic recurring fear that "also, of course, it gives an opportunity for the nobility, the nobles, to also capture power, because of the [Democratic Party] fragmentation" (Hill, 2014).

I think though, on the other hand, that there is some dissension between the ranks of even the Friendly Islands Party Movement [Democratic Party of the Friendly Islands], so there is now some disunity within the movement and so we're getting, we're starting to see the possibility of perhaps it fragmenting and people go off in groups of their own and one of the problems with that is that it doesn't give a very good picture of democrats cooperating and also, of course, it gives an opportunity for the nobility, the nobles, to also capture power, because of the fragmentation. (Malakai Koloamatangi cited in Hill, 2014).

Why was the nobility's collective potential to assume government leadership shrouded in, and contorted by, suspicion and scepticism? To begin with there was Kalafi Moala's belief that "elected officials [should] be running the government," meaning parliamentarians elected by Tongan voters registered on the general roll. An in-house election for Tonga's thirty three hereditary title and estate-holders to elect nine nobles to parliamentary seats representing their class group, was now written off as undemocratic because the nobility were not voted in by the people. 
The hot conversation going on in Nuku'alofa today is that the nine nobles' seats must be abolished. Why have nine seats for 33 nobles? Why can't all the members of parliament be people's representatives elected by the people? If a noble wants to enter parliament he will need to run as a people's representative. This change may not happen before November's election but it promises to be the key issue for political reform in the next several years, definitely before the 2018 election. (Moala, 2014c).

A hypothesis ensued: If the nobility stood for election to the commoners' constituencies was there a likelihood that nobles well regarded by people living on their estates would be voted into parliament? Could Lord Ma'afu win the people's representative seat for Tongatapu 8 if he stood for Vaini district on his estate? What might result from Lord Nuku contesting the eastern district seat for constituency Tongatapu 10 where his estate and principal village of Kolonga was located? Quite believably, yes; Ma'afu and Nuku would win the popular vote for Tongatapu 8 and Tongatapu 10. Their own people, especially the kainga (kinfolk), would vote for them before a commoner.

Given the scenario that members of the noble class could convincingly win people's representatives seats, would this reduce the chances of commoner candidates getting elected to parliament? If the nobility took out more people's representative seats than the commoners, would this make the parliamentary electoral system more democratic in terms of dispersing power among the majority of ordinary Tongans?

No, certainly not was the correct answer, which elicited crucial scrutiny. Originally, the Democratic Party proposed to end the nobles' election for nine seats, forcing the nobility to stand for parliament in the general election for seventeen 
people's representatives. Midstream, the thinking shifted to downsizing to three seats set aside for the nobility, presenting a workable compromise in which the people's representatives explicitly held the dominant numbers to win the prime minister's election and become the government, while allowing a few nobles to hang in there. Subversively, pro-democracy politicians had figured out the odds of getting beaten at the finishing post by popular nobles standing against them in the general election. Devising a watertight plan B, an improved blueprint would let them get their hands on all the power they desired.

Essentially, the Democratic Party disputed whether a parliamentary system with seats reserved only for the nobility to designate nine members of their class had a democratic mandate authorised by Tongan voters. The bone they had to pick was rooted in grievance. In 2010, they failed to outdo the nobles' candidate at the parliamentary vote for prime minister, and blamed the electoral system for outdoing them. However, plotting to displace the nobles from their own election and seats by transferring the whole lot of them to the general election was a redundant manoeuvre. As a political union distinguished by class and culture, the nobility possessed the expertise to regroup and mobilise to win the majority of seventeen people's representative seats.

Propelling the flawed logic was that the Democratic Party and pro-democracy supporters did not count the political composition of chambers of parliament as relevant to Tonga (Shapley and Shubik, 1954). Because the nobility and the commoners convened under one debating chamber forming a national executive from both class groups, Tonga's legislative assembly did not resemble a bicameral system of an upper and lower house with separate functions. Understandably then, conceptualising chambers of parliament was overlooked as an underlying principle that organised national polity and 
governance. The concept and practice, however, did intersect in Tonga's political organisation in a subtle but none the less salient way.

For all intents and purposes, meaning in every practical sense of how the state bureaucracy of governing power works, reasons, and behaves, Tonga was a unicameral structure of one legislative chamber. But the one House seated two classes, categories, and ranks of parliamentarians whose cultures, customs, and civilisations purposely diverged and fervidly disagreed when a reappearing crop of political stressors materialised, heading into a general election; for example, the Democratic Party lobbying for Tonga to adopt Western liberal democracy as the national political arrangement.

Contextually, timing was of strategic importance because campaigning for Western liberal democracy only became loud and disruptive to social order as an election carrot to recruit voters. The intense politicking, voter canvassing, and politician speech-making prior to the general election held four-yearly triggered an excitable, emotional, and volatile underclass of vulnerable groups coerced into thinking democracy, the Western liberal kind, presented an election issue for all Tongans; not that it did, which is the point I am hammering. Rather, it was the timeliness of the Democratic Party appealing to voters who saw themselves as dispossessed in a social hierarchy a few months out from polling day, which deliberately polarised and intensified class divisions in the legislative assembly.

An after-effect was that ritualistically the nobility and the commoners kept their minds on preserving the different cultures, customs, and civilisations of their classes. This amplified and politically manufactured over-the-top interval of political instability that fed, bred, and spread during an election year was anticipated. The no-win situation of political 
hostilities transacted between noble politicians and prodemocracy politicians who were not about to resolve opposing stances, seemed to have deepened the class boundary in 2014, the year of the second election after Tonga was constitutionally remade more democratic.

In one way, Kalafi Moala's allusion to performing Tongan politics while "retaining the uniqueness of our culture and social structure" intimated around carrying on with endless and uncompromising class tension; frictions and factions produced by the structural constraints of a parliament setting rooming two ranks of people who, by constitutional decree, were afforded very different roles and responsibilities to play in the one system (Moala, 2008, p. 184).

Under election pressure, the nobility converged and concentrated on protecting privileges guaranteed as their constitutional entitlement. Equally under pressure to get reelected, pro-democracy people's representatives, whether affiliated to the Democratic Party or independent members, revealed hankerings to revoke the nobles' constitutional benefits of having nine parliamentary seats and roles of speaker and deputy speaker of the House assigned only to their class and kind.

Contrary to cut-throat political enmities, Malakai Koloamatangi assessed Tonga's election landscape three months away from November 27th polling day. He thought the country had travelled some distance from setting up the pro-democracy movement in the 1980s through to seeing the 2010 political reform instituted. Tongan people in 2014, the ordinary voters on the general roll, had arrived at a new destination where they were now "looking for something different" in the elected parliamentarians (Hill, 2014). They wanted political leadership that would give Tonga secure direction into an unknown future. 
But I think people are looking for something different also, I think they are looking for people who are visionary, in a sense that, what comes after we get democratic government, what's going to happen. I mean how is that going to benefit the lives of people, so people are starting to look perhaps to the future more and in this election I think it shows that democracy is accepted and it's been institutionalised, and whilst it [will] take some time for it to be culture-related in Tonga, people accept it for what it is and they're moving forward from that. (Malakai Koloamatangi cited in Hill, 2014).

If any cultural truth existed in Koloamatangi's assertion that Tongan "people are looking for something different also" in political candidates standing for seventeen parliamentary seats assigned to people's representatives, then voters' sentiments that the economy was an election urgency prompted the swing in preferences and priorities (Hill, 2014). The long running saga of the Democratic Party scheming for power had reached public saturation point. To be brutally honest, it was a widely held assumption that 'Akilisi Pohiva had done his dash as a career politician of almost thirty years, signifying that people were surveying the range and scale of candidates for newness and change; a decided and decisive move towards "nominative answers to Tonga's [economic development] problems" at the constituency level of communities, villages, and districts (Hill, 2014).

Noting this point to Bruce Hill of Radio Australia, Koloamatangi confessed that "people seem less interested in political reform these days," and that "the economy will be an important issue at the election" (Hill, 2014). Significantly, voters had shifted their ranking of election interests to "looking for answers to development problems that Tonga has. And so 
if someone can offer a message around that, I think [he or she] will be [a] very popular candidate," announced Koloamatangi (Hill, 2014).

Which brings me to suggest that Tongan voters adjusting their lens to look closely at the "development problems Tonga has" was patently motivated by international relations (Hill, 2014). Certainly, the horde of foreign embassies located in Nuku'alofa, and the reality that the Tu'ivakano government had pivoted to China and Asia as fundamental sources of aid assistance for national development projects, fashioned how ordinary Tongans grasped the gamut of development dilemmas and donors influencing their country's economy, politics, and foreign policy.

\section{Sovereignty not democracy}

In the Asia-Pacific region, including the small island developing states, there were two models at work for modern state and society, bureaucracy or military. While it was true that bureaucracy predominated and proliferated among the Pacific Island states, when it failed, the military stepped in as the backup to restore law and order, in theory. Of course the 2006 to 2014 military state central to shaping the 21 st century regional economy and polity was the Republic of Fiji. Aptly, Fiji's post-1970 political independence from the vestiges of a colonial British Empire, demonstrated that the government of a Pacific Island state brought into force by the armed services was capable of mobilising beyond the reestablishment law and order into "the order of things," meaning the dominant pattern of political thought and behaviour (Foucault, 1970).

By this, a military leader carrying out a coup could rewrite the constitution, and after the coup fulfilled its political purpose, evade the threat of court action for executing a military seizure of the state, and get democratically elected to 
government as the prime minister. Sitiveni Rabuka's election as Fiji's third prime minister from 1992 to 1999 proved this was doable down-to-a-T. In 1987, Rabuka carried out two military coup-de-tat deposing the coalition government of five political parties led by Prime Minister Dr Timoci Bavadra who defeated the inaugural Prime Minister Ratu Kamisese Mara's Alliance Party by twenty eight seats to twenty four. On top of that, he assumed Fiji's prime ministership for two consecutive terms leading the Fijian Political Party government.

A repeat of the same scene starring new political actors looked to screen again. Leading up to the Fiji general election set for September 17th 2014, popular guesswork picked Frank Bainimarama and his Fiji First Party to be the favourites. He had executed two coups in history; the first in putting down the pro-indigenous Fijian putsch of George Speight in 2000; and the second in 2006 deposing the elected Prime Minister Laisenia Qarase, a pro-indigenous Fijian politician from Vanuabalavu Island in the Lau group.

An election had not been held for eight years of which during that time, Bainimarama reinvented his public profile from the military coup leader dressed in officer's uniform who took over the prime minister's office on January 5th 2007. Almost a decade on, he acted the part of the Republic of Fiji's Prime Minister, a rare admiral and retired naval officer who made public reference to "the people of Fiji," as if the history of race and power politics between i-Taukei [indigenous Fijians] and Fiji Indians had been resolved, absolved, and dissolved in his eight years of steering the government ship.

This simply was not so, and what Bainimarama's electioneering rallies exposed, particularly for his public address held at the Manukau Events Centre in Auckland, New Zealand on August 9th 2014, was his support base appeared to be somewhat racially lop-sided (Anneberg and Kata, 2014). Outsider observations of non-Fiji nationals expressed that 
Bainimarama's popular vote did not come from his own ethnic kind, $i$-Taukei. Instead, Fiji Indians from across the religious divide of Hindu and Muslim gave rise to his post-coup power and race relations by joining forces to get him elected.

Lord Ma'afu during the Tu'ivakano administration's fouryear term as Minister for Lands and Natural Resources, had built up a regional profile as the Tongan government's straight shooter. He came out firing at Frank Bainimarama's tactics in Fiji's domestic affairs. Ma'afu was no fan of Bainimarama's 2012 disestablishment of the great council of chiefs, a constitutional body instated in 1897 under the British governor Arthur Gordon.

The council had served as a 19th century institution for hereditary chiefs to select and appoint Fiji's president and vice president, and a clear majority of the senate's thirty four seats. When the military junta assumed power in 2007, conflict erupted between the council's function and Bainimarama's desire to flatten racial tension between i-Taukei and Fiji Indians by expelling the chiefs' authority in state governance.

As a high-ranking hereditary chief of Tonga with kinship connections to the chiefly class of Fiji's Lau group, Ma'afu's view was cut-and-dry. Here, I mean that his judgement reflected his class position in a hierarchical Tongan society ordered by chiefly rank, and in all honesty, conveyed the consensus of Tonga and Fiji's aristocracy. Ma'afu strongly believed the Fijian chiefs must have a say in the running of their country's affairs by way of institutionalised involvement in state governance at the national level of decision making.

Unflinchingly, he put it out there in public media to Fijian reporter for Tonga Daily News, Iliesa Tora. The "Nobles in Parliament hold the key to keeping Tonga stable and peaceful," he avowed (Tora, 2014). Sharply pointing the finger at Fiji's fourth constitution of September 2013 orchestrated by the Bainimarama regime, Ma'afu passionately disagreed with 
eradicating the great council of chiefs, the senate, the $i$-Taukei electoral roll, and the reserved parliamentary seats for $i$ Taukei. He was adamant that "Tonga should learn from the Fiji situation as the push for democracy continues here in the Kingdom," and not go down the same rickety path (Tora, 2014).

He argued bluntly if the Democratic Party carried on plugging for Tonga's constitutional monarchy to convert into a Western liberal democracy, extinguishing the nobility from parliamentary representation, the state and citizens "could see Tonga losing out in the end" (Tora, 2014). Without nobles in the legislature to act as the traditional balance of power, to protect land interests for ethnic Tongan nationals, and to be the conservative centre of the political spectrum, Tonga as its citizens knew it, could basically dissolve into political disorder collapsing the government, and cutting away at the country's cultural fabric.

Yes democracy is good but Tonga's situation is different from New Zealand or Australia for that matter. The nobles in Parliament are there to help ensure that Tonga and what Tongans hold dear to their hearts are protected. You only have to look at Fiji and see what has happened there and is happening with the chiefs there having no say in the status of the country. That's the price they are paying. Nobles are there for a purpose because we look after our people. (Lord Ma'afu cited in Tora, 2014).

A sub-text opened out. Really, Ma'afu interrogated sovereignty not democracy. His New Zealand socialisation experience was sounder than the Democratic Party members of parliament advocating for Western liberal democracy who, if the truth be told, had little if any first-hand experience of 
living in a Western democratic country as a Tongan and Pacific Islander ethnic minority. Migrating to New Zealand for private boarding school education at Wanganui Collegiate, Tonga's Minister for Lands was personally familiar with the New Zealand political system that pro-democracy activists coveted. He debunked what they craved for because as he put it straightforwardly, "democracy is good but Tonga's situation is different from New Zealand or Australia for that matter" (Tora, 2014).

To Ma'afu the difference, quite frankly, hinged on sovereignty; a term, concept, practice, a complete system of power constituting Tongan state and society, which for some illusive reason Democratic Party parliamentarians did not mull over when plotting to permanently rig seating arrangements in the House so only the commoners could be the government. He felt griped that missing from social memory was the Tongan monarch. Written into the constitution as "the Sovereign of all the Chiefs and all the people," the sovereign's power centred on being the sole signatory verifying "Acts that have passed the Legislative Assembly" had met with his approval to "become law" (Kingdom of Tonga, 1988b, p. 17).

\section{King's powers - Signature to Acts}

The King is the Sovereign of all the Chiefs and all the people. The person of the King is sacred. He governs [amended in 2010 to "He reigns"] the country but ministers are responsible. All Acts that have passed the Legislative Assembly must bear the King's signature before they become law. (Kingdom of Tonga, 1988b, p. 17).

Personifying the sovereign's authority, therefore, were the dual executive powers of head of state and commander in chief of His Majesty's Armed Forces. Unequivocally, the King of 
Tonga embodied national sovereignty; sovereignty defined as a Tongan, not Western European, constitutional monarchy. And here lay Ma'afu's piercing point: Was it not hypocritical for pro-democracy campaigners to pay token lip-service to practicing a democracy that averts "tearing up the basic fabric of Tongan social structure" when in real politik that is exactly what was planned? (Moala, 2008, p. 184).

By Ma'afu's judgement, the Democratic Party had surreptitiously shown no resolve to preserve true national sovereignty by "retaining the uniqueness of our culture and social structure" (Moala, 2008, p. 184). To him, they looked and behaved like a spurious version of culture and society. Purposefully they adopted a quasi-Western political consciousness, and double-dealt the poorest of the common class by telling them it was suited to Tongan sovereignty and way of life. Plainly, they were duped and intent on duping those of a weak financial and social position in the hierarchy to garner political support.

The unique feature about Tongan sovereignty was that the monarch and the nobility were written into the constitution in unison. The "covenant binding on the King and chiefs of this Kingdom for themselves and their heirs and successors for ever," as the constitution proclaimed, was that Tonga's lands were effectively "the property of the King" which he conferred on the nobility, including matapule (minor chiefs), as "their hereditary estates" to remain in their male lineage from father to eldest son (Kingdom of Tonga, 1988b, p. 30). As indicative of 19th century missionary Christianity as the Act of Constitution of Tonga was, the biblical notion that this covenant obligated the King to the nobles and vis-à-vis wholly fortified and armour-plated Tongan sovereignty in the presentday.

Reading Ma'afu closely and carefully, he connoted that for pro-democracy politicians to even suggest subtracting the 
nobility from the parliamentary equation weakened the sovereign's constitutional right to reign in conjunction with the landed gentry's patronage. Essentially, this was the destructive force in Tongan political life; an attack on sovereignty. Why would a titled noble with a hereditary estate by constitutional law, a Minister of Lands and Natural Resources, and a former military officer of His Majesty's Armed Forces, be expected to think any differently? (James, 1995; Marcus, 1978).

\section{Endnote on the end}

Sincerely, I did not intend to give prominence to Lord Ma'afu's international relations efforts as Tonga's Minister for Lands and Natural Resources in this essay. The truth is that going on three years since I first published the journal article called, Ma'afu's Word is in the Hills: What is a Noble's Role in a Democratised Tonga? in 2012, I have written seventeen essays on Tonga's development all up; this one included. Looking back, Ma'afu was and is central to my authorship.

For this article, his work at regional level for seabed minerals and coastal fisheries cropped up at the time I was researching this paper, and ended up rejigging the hypothesis to read: Is it true or false that international relations has greater influence on the state than internal affairs? The short reply is in Tonga's circumstance, it is indeed true.

A senior cabinet minister with considerable clout in government; a high-ranking noble persuasive in effecting the nobility's collective stance; and the one Tongan politician of the landed gentry confident and capable to respond to problems, uncertainties, pokes, and probes I jostled at him, he never defaulted on tendering an answer. Ma'afu has given a lot to me in the four years I have known him as a minister; a lot to mill through, pick at, interrogate, make sense of, and 
publish; a lot of time, care, and thought explaining why government policy ought to travel this route; not feeding me shallow propaganda that I would see straight through and blast him for.

This is not to say I have stood in out-and-out agreement with Ma'afu's ministerial policies. The Government of Tonga's endorsement of seabed mineral exploration and exploitation at high seas provoked a volley of heated and quarrelsome exchanges between me and the Minister for Lands and Natural Resources, which I have written in detail and published (Brown Pulu, 2013a). To this day, I am not convinced seabed minerals is a fail-safe income earner for Tonga; nor does this small island developing state have sure-fire protection against liability for environmental loss and damage caused by deep sea mining companies. But enough trust and respect for one another's views, no matter how divergent, has been reciprocated between us for me to at least hear the minister out, listen conscientiously to the policy rationalisation, and study the reasoning earnestly.

In all probability, it is befitting that I close my collection of seventeen essays published on Tongan politics and society during the Tu'ivakano government from 2010 to 2014 with a Ma'afu oriented paper. That was the way I began in 2012 by penning Ma'afu's Word is in the Hills, and that is how I feel somewhat duty-bound to conclude.

I told Ma'afu that this would be the last paper I author on Tonga before Election Day arrives on November 27th 2014. Then again, who really knows, as when it comes to making predictions about how this small island development state goes about patching up rising seas greedily gulping coral islands, and sorting out an epidemic spread of parliamentary chaos, an intricate story waits to unfurl. 


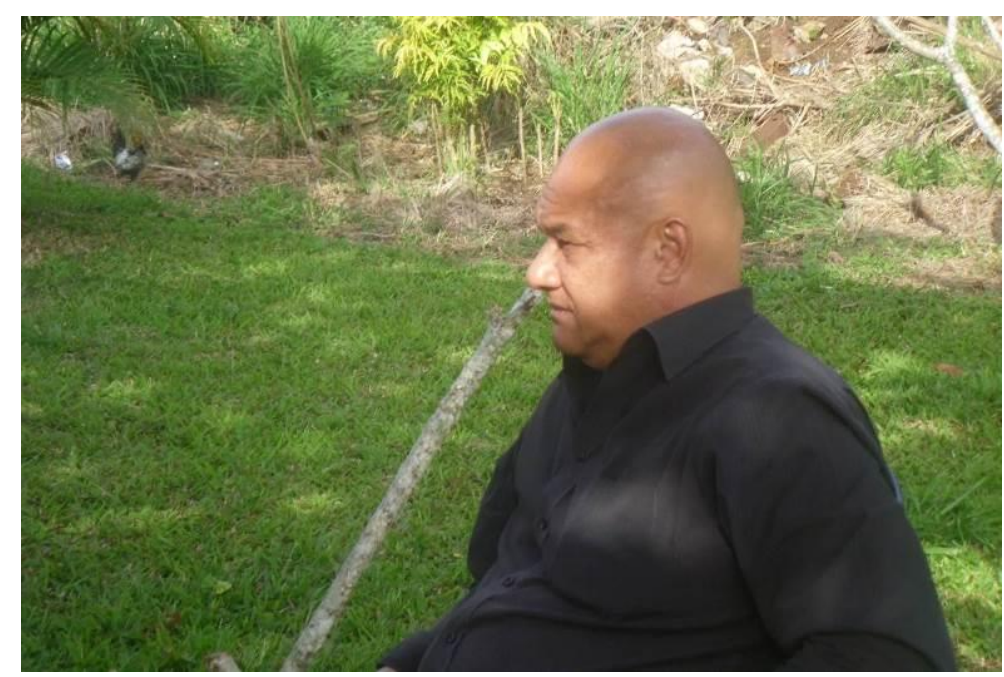

Lord Ma'afu of Vaini and Tokomololo, head of the Ha'a Havea Lahi, and Minister for Lands and Natural Resources at the Government of Tonga. Photograph taken at Vaini village in Tonga's central district by Teena Brown Pulu, 2011.

If I made one observation as a researcher about the tumultuous give-and-take relationship grown over four years of getting to know the noble politician and Minister for Lands and Natural Resources Lord Ma'afu, and how he operates in national and regional politics, then it is this. He has never told me to quit writing about Tonga, even when I fired scathing criticism at his conservative upper-class mindset, and the hard-line manoeuvring he used to get his way in cabinet and parliament to go charging after seabed mining, because a writer must write.

So too must a politician demonstrate his abilities, or in Ma'afu's case engage in real politik, power politics. That is what we do in the world, and there is no need whatsoever to cancel one another out. My long-suffering hope shared by many Tongans is that parliamentarians from the commoner 
class can politically mature to learn this lesson well, and practice its ethic. 


\section{References}

Anneberg, M. and Kata, A. (2014). Protestor's challenge

Bainimarama's election visit to NZ. Pacific Scoop: AUT's Pacific

Media Centre, Auckland, New Zealand, August 11. Retrieved from

http:/ / pacific.scoop.co.nz/2014/08/protesters-challenge-

bainimaramas-election-visit-to-nz/

Bola-Bari, V. (2014a). Old politics must go: Bainimarama. Fiji Live, Suva, Fiji, July 26. Retrieved from

http:/ / fijilive.com/news/2014/07/old-politics-must-go-

bainimarama/58400.Fijilive

Bola-Bari, V. (2014b). FijiFirst names first batch of candidates. Fiji Live, Suva, Fiji, July 25. Retrieved from

http:/ / fijilive.com/news / 2014/07/fijifirst-names-first-batch-ofcandidates/58399.Fijilive

Briguglio, L. (1995). Small Island Developing States and Their

Economic Vulnerabilities. World Development, 23 (9): 1615-1632.

Brown Pulu, T. (2014a). Off the Deep End: Tonga's Continental Shelf Politics. Te Kaharoa: The e-Journal on Indigenous Pacific Issues, 7 (1): 173-244.

http://www.tekaharoa.com/index.php/tekaharoa/article/view/171/1 $\underline{29}$

Brown Pulu, T. (2014b). Who Owns Tonga? Dialogues with Sefita Hao'uli, Kalafi Moala, and Melino Maka. Te Kaharoa: The eJournal of Indigenous Pacific Issues, 7 (1): 113-162.

http://www.tekaharoa.com/index.php/tekaharoa/article/view/169/1 $\underline{27}$

Brown Pulu, T. (2013a). Deep Sea Tension: The Kingdom of Tonga and Deep Sea Minerals. Te Kaharoa: The e-Journal on Indigenous Pacific Issues, 6 (1): 50-76.

http://www.tekaharoa.com/index.php/tekaharoa/article/view/145/1 $\underline{03}$

Brown Pulu, T. (2013b). Climate Change Blues: Sustaining Village Life in Tonga. Te Kaharoa: The e-Journal on Indigenous Pacific Issues, 6 (1): 260-305.

http://www.tekaharoa.com/index.php/tekaharoa/article/view/152/1 $\underline{10}$

Brown Pulu, T. (2011). Shoot the Messenger: The Report on the Nuku'alofa Reconstruction Project and Why the Government of Tonga Dumped It. Nuku'alofa, Tonga: Taimi Publishers. 
Buchholz, H. J. (1987). Law of the Sea Zones in the Pacific. Pasir Panjang, Singapore: Institute of Southeast Asian Studies.

Campbell, I. C. (2004). Tongan Development and Pacific Island Security Issues. In The Asia Pacific: A Region in Transition, edited by J. Rolf. Honolulu, Hawai'i, United States: Asia-Pacific Center for Security Issues, Pp. 335-354.

Coutts, G. (2014a). Coastal fisheries in need of protection. Pacific Beat: Radio Australia: Australian Broadcasting Corporation, Melbourne, Australia, August 14. Retrieved from

http://www.radioaustralia.net.au/international/radio/program/pacifi c-beat/coastal-fisheries-in-need-ofprotection/1356818?autoplay $=1356870$

Coutts, G. (2014b). IUCN calls on fisheries ministers to widen focus beyond tuna. Pacific Beat: Radio Australia: Australian Broadcasting Corporation, Melbourne, Australia, August 5. Retrieved from

http://www.radioaustralia.net.au/international/radio/program/pacifi c-beat/iucn-calls-on-fisheries-ministers-to-widen-focus-beyondtuna/1352862

Coutts, G. (2011). Fiji and Tonga dispute ownership of Minerva Reefs. Pacific Beat: Radio Australia: Australian Broadcasting Corporation, Melbourne, Australia, February 11. Retrieved from

http://www.radioaustralia.net.au/international/radio/onairhighlights Lfiji-and-tonga-dispute-ownership-of-minerva-reefs

Derrida, J. (1999). Forgiving the Unforgivable: Public Lecture. Auckland Town Hall, Auckland, New Zealand, August 18.

De Souza, R. (2014). What does it mean to be political? Ruth De Souza: Nurse Academic in Australia, Melbourne, Australia, August 3. Retrieved from

http://www.ruthdesouza.com/2014/08/03/what-does-it-mean-to-bepolitical/

Fonua, P. (2014). Cabinet tries to take control of Judiciary. Matangi Tonga Online, Nuku'alofa, Tonga, August 23. Retrieved from http://matangitonga.to/2014/08/23/cabinet-tries-take-controljudiciary

Foucault, M. (1988). "Practising Criticism," or "Is it really important to think?" May 30-31, 1981. Didier Eribon interview. In Foucualt, Politics, Philosophy, Culture, edited by Lawrence Kritzman. New York and London: Routledge, P. 155. 
Foucault, M. (2004). Security, Territory, Population: Lectures at the College de France 1977 - 1978, edited by Michel Senellart. New York, United States: Picador and Palgrave Macmillan.

Garrett, J. (2014). Unfinished business in Tonga's political reform needs attention says expert. Radio Australia Pacific Beat: Australian Broadcasting Corporation, Melbourne, Australia, April 30. Retrieved from

http://www.radioaustralia.net.au/international/radio/program/pacifi c-beat/unfinished-business-in-tongas-politcal-reform-needsattention-says-expert/1303624

Gough, L. (2011). C. Northcote Parkinson's Parkinson's Law: A ModernDay Interpretation of a Management Classic. Oxford, United Kingdom: Infinite Ideas Limited.

Government of Tonga. (2014). Tonga's election to the Council of the ISA. Ministry of Information and Communications: Government of Tonga, Nuku'alofa, Tonga, July 25. Retrieved from

http:/ / www.mic.gov.to/news-today/press-releases/5027-tongaselection-to-the-council-of-the-isa

Graue, C. (2014). Progress in Fiji under Bainimarama, says Tonga's democracy leader. Radio Australia: Pacific Beat: Australian Broadcasting Corporation, Melbourne, Australia, July 8. Retrieved from

http://www.radioaustralia.net.au/international/radio/program/pacifi c-beat/progress-in-fiji-under-bainimarama-says-tongasdemocracy-leader/1339508

Hansard Tonga. (2014a). Ko e Miniti 'o e Feme'a'aki 'a e Hou'eiki Memipa 'o e Fale Alea 'o Tonga: Fika 31, Efiafi Tusite 19 'Aokosi 2014. Parliament of Tonga, Nuku'alofa, Tonga, August 19.

Hansard Tonga. (2014b). Ko e Miniti 'o e Feme'a'aki 'a e Hou'eiki Memipa 'o e Fale Alea 'o Tonga: Fika 15, Efiafi Pulelulu 23 Siulai 2014. Parliament of Tonga, Nuku’alofa, Tonga, July 23.

Hayward-Jones, J. (2009). Policy Brief: Fiji: The Flailing State. Lowy Institute for International Policy, Sydney, Australia, April, Pp. 1-12.

Hill, B. (2014). Tonga election likely to focus on the economy. Radio Australia Pacific Beat: Australian Broadcasting Corporation, Melbourne, Australia, August 20. Retrieved from

http://www.radioaustralia.net.au/international/radio/program/pacifi c-beat/tonga-election-likely-to-focus-on-economy/1359006

International Seabed Authority. (2014a). The Council. International Seabed Authority, Kingston, Jamaica, July 29. Retrieved from 
http://www.isa.org.jm/en/about/members/council

International Seabed Authority. (2014b). International Seabed Authority Ends Historic Session. International Seabed Authority, Kingston, Jamaica, July 28. Retrieved from http://www.isa.org.jm/en/node/1004

ISA Press Release. (2014a). International Seabed Authority Press Release: Twentieth Session, Kingston, Jamaica, $14-25$ July 2014: Round Up of Session, SB/20/17, July 25, Pp. 1-9.

ISA Press Release. (2014b). International Seabed Authority Press Release: Twentieth Session, Kingston, Jamaica, 14 - 25 July 2014: Assembly (PM), SB/20/16, July 24, Pp. 1-3.

ISA Press Release. (2014c). International Seabed Authority Press Release: Twentieth Session, Kingston, Jamaica, $14-25$ July 2014: Assembly (AM), SB/20/15, July 24, Pp. 1-4.

IUCN. (2014a). Pacific countries look to next steps following call for action on coastal fisheries and beche-de-mer. IUCN: International Union for the Conservation of Nature, Switzerland, August 12. Retrieved from

http://www.iucn.org/about/union/secretariat/offices/oceania/? 18230/Pacific-countries-look-to-next-steps-following-call-foraction-on-coastal-fisheries-and-beche-de-mer

IUCN. (2014b). Is it time for certification and branding of sustainablygrown products from Pacific coastal fisheries? IUCN: International Union for the Conservation of Nature, Switzerland, August 7. Retrieved from

http://www.iucn.org/about/union/secretariat/offices/oceania/?1822 2/Is-it-time-for-certification-and-branding-of-sustainably-grownproducts-from-Pacific-coastal-fisheries

IUCN. (2014c). Pacific Islanders will need alternative sources of protein within two decades if current overfishing continues. IUCN: International Union for the Conservation of Nature, Switzerland, August 6. Retrieved from

http://www.iucn.org/about/union/secretariat/offices/oceania/?1821 5\%2FPacific-Islanders-will-need-alternative-sources-of-proteinwithin-two-decades-if-current-overfishing-continues\#.UKlOWrKD8A.twitter

IUCN. (2014d). Challenges facing management of coastal fisheries and beche-de-mer in the Pacific. IUCN: International Union for the Conservation of Nature, Switzerland, August 5. Retrieved from 
http://www.iucn.org/about/union/secretariat/offices/oceania/?1721

$0 /$ Challenges-facing-management-of-coastal-fisheries-and-bechede-mer-in-the-Pacific

James, K. (1995). Right and Privilege in Tongan Land Tenure. In Land, Custom and Practice in the South Pacific, edited by R. G. Ward and E. Kingdon. United Kingdom: Cambridge University Press, Pp. 157-197.

Kingdom of Tonga. (2014). Executive Summary: A Partial Submission of Data and Information on the Outer Limits of the Continental Shelf of the Kingdom of Tonga in the Western Part of the LauColville Ridge Pursuant to Part VI of and Annex II to the United Nations Convention on the Law of the Sea, Part I. Kingdom of Tonga, April, Pp. 1-39. Retrieved from

http://www.un.org/depts/los/clcs_new/submissions_files/ton73_14/ Part_I_Executive_Summary.pdf

Kingdom of Tonga. (2007). Territorial Sea and Exclusive Economic Zone Act: 2007 Revised Edition. Kingdom of Tonga, Nuku'alofa, Tonga, October 1.

Kingdom of Tonga. (1988a). Minerals Act: 1988 Revised Edition. Kingdom of Tonga, Nuku'alofa, Tonga, Original Commencement on November 25, 1949.

Kingdom of Tonga. (1988b). Act of Constitution of Tonga: 1988 Revised Edition. Kingdom of Tonga, Nuku'alofa, Tonga, Original Commencement on November 4, 1875.

Kingdom of Tonga. (1988c). Land Act: 1988 Revised Edition. Kingdom of Tonga, Nuku'alofa, Tonga, Original Commencement on August 27, 1927.

Latu, K. (2014a). Tonga's constitution costly, poorly written and undemocratic, says report. New Zealand Kaniva Pacific, Auckland, New Zealand, July 23. Retrieved from

http://www.nzkanivapacific.co.nz/2014/07/tongas-constitutioncostly-poorly-written-and-undemocratic-reportsays/\#.U9AGJ7FWnTo

Latu, K. (2014b). MP Sione Taione breaks his silence after being dropped from Democratic Party candidates' list. New Zealand Kaniva Pacific, Auckland, New Zealand, July 17. Retrieved from

http://www.nzkanivapacific.co.nz/2014/07/mp-sione-taione-breakssilence-dropped-democratic-party-candidateslist/\#.U_097WPEbTo 
Marcus, G. E. (1978). Chapter 3: The Nobility in the Transmission of a Chiefly System to Modern Tonga. The Journal of the Polynesian Society, 87 (42): 43-73.

Matangi Tonga. (2010). Download full results from Tonga's polling places. Matangi Tonga Online, Nuku'alofa, Tonga, November 26. Retrieved from

http:/ / matangitonga.to/2010/11/26/download-full-results-tongaspolling-places

McCourt, F, (1996). Angela's Ashes: A Memoir. New York, United States: Simon and Schuster Incorporated.

Mearsheimer, J. (2014). The Tragedy of Great Power Politics. New York, United States: W. W. Norton and Company, Incorporated, Updated Edition.

Mindle, G. (1985). Machiavelli's Realism. The Review of Politics, 47 (2): 212-230.

Ministry of Environment and Communications. (2014). Pacific Small Island States Project's Ground Breaking Ceremony. Ministry of Environment and Communications: Government of Tonga, Nuku'alofa, Tonga, August 15. Retrieved from

http://www.mic.gov.to/news-today/press-releases/5074-pacificsmall-island-states-projects-ground-breaking-ceremony

Moala, K. (2014a). Tonga's new constitution is the worst in the Commonwealth. Pacific Politics: Political news and analysis bought to you by the Pacific Institute of Public Policy, Port Vila, Vanuatu, August 11. Retrieved from

http://pacificpolitics.com/2014/08/tongas-new-constitution-is-theworst-in-the-commonwealth/

Moala, K. (2014b). Tonga: A reformist old warrior's political agenda. Pacific Scoop: AUT's Pacific Media Centre, Auckland University of Technology, Auckland, New Zealand, March 4. Retrieved from

http:// pacific.scoop.co.nz/2014/03/tonga-a-reformist-old-warriorspolitical-agenda/\#more-22249

Moala, K. (2008). Media and Conflict in the Kingdom: The Case of Taimi 'o Tonga. In South Pacific Islands Communication: Regional Perspectives, Local Issues, edited by E. Papoutsaki and U. Sundar Harris. Singapore: Asia Media Information and Communication Centre (AMIC), Nanyang Technology University, Pp. 175-185.

Northcote Parkinson, C. (1957). Parkinson's Law. New York, United States: Buccaneer Books Incorporated. 
One News. (2011). Yachties warned not to put down anchor on reef. ONE News: Television New Zealand, Auckland, New Zealand, February 10. Retrieved from

http://tvnz.co.nz/world-news/yachties-warned-not-put-downanchor-reef-4021500

Osborne, J. (2014). Democratic Transition in the Development Context: The Case Study of Tonga, Master of Development Studies, Victoria University of Wellington, Wellington, New Zealand, Pp. 1-98.

Orwell, G. (1949). Nineteen Eighty-Four: A Novel. London, United Kingdom: Secker and Warburg.

Perrottet, A. (2011). Human rights advocate blasts 'paternalistic' Pacific leaders. Pacific Scoop: AUT's Pacific Media Centre, Auckland, New Zealand, September 6. Retrieved from

http:/ / pacific.scoop.co.nz/2011/09/human-rights-advocate-blastspaternalistic-pacific-leaders/

Radio New Zealand. (2014a). Call for Tongan MPs to work together. Radio New Zealand International, August 27. Retrieved from

http:/ / www.radionz.co.nz/international/pacific-news /253087/callfor-tongan-mps-to-work-together

Radio New Zealand. (2014b). Tonga's Halapua encourages collegial governments. Radio New Zealand International, August 26.

Retrieved from

http://www.radionz.co.nz/international/pacificnews/253039/tonga\%27s-halapua-encourages-collegialgovernments

Radio New Zealand. (2014c). Tonga's Pohiva confident despite rifts. Radio New Zealand International, August 25. Retrieved from

http:/ / www.radionz.co.nz/international/pacificnews / 252924/tonga\%27s-pohiva-confident-despite-rifts

Radio New Zealand. (2005). Tonga dismisses Fiji's claim on Minerva Reef. Radio New Zealand International, October 31. Retrieved from http://www.radionz.co.nz/international/pacific-news/158359/tongadismisses-fiji\%27s-claim-on-minerva-reef

Radio Tonga. (2014). Radio Tonga News in English. Radio Tonga: Tonga Broadcasting Commission, August 20, 1.30 pm.

Shapley, L. and Shubik, M. (1954). A Method for Evaluating the Distribution of Power in a Committee System. American Political Science Review, 48 (3): 787-792. 
Spivak, G. C. (1990). The Post-Colonial Critic: Interviews, Strategies, Dialogues. London and New York: Routledge.

The Tonga Herald. (2014a). Demo party leader asks China to intervene and influence domestic politics. The Tonga Herald: We Are The Future, Nuku'alofa, Tonga, July 29. Retrieved from

http://tongaherald.com/demo-party-leader-asks-china-to-interveneand-influence-domestic-politics/

The Tonga Herald. (2014b). PTOA Chair pre-emptively purging party 'dissidents' for fear of being ousted? The Tonga Herald: We Are The Future, Nuku'alofa, Tonga, July 10. Retrieved from

http:/ / tongaherald.com/ptoa-chair-preemptively-purging-partydissidents-for-fear-of-being-ousted/

Tonga Daily News. (2014a). Judiciary Should Be Independent: Lord Fakafanua. Tonga Daily News, Nuku'alofa, Tonga, August 14. Retrieved from

http://www.tongadailynews.to/?p=7901

Tonga Daily News. (2014b). Proposed Constitutional and Legislative Amendments in Relation to the Judiciary. Tonga Daily News, Nuku'alofa, Tonga, July 31. Retrieved from

http:/ / www.tongadailynews.to/?p=7645

Tonga Daily News. (2014c). Pohiva Applauds Bainimarama. Tonga Daily News, Nuku'alofa, Tonga, July 3. Retrieved from

http://www.tongadailynews.to/?p=7160

Tonga Daily News. (2014d). Six Departments Merged as One Ministry. Tonga Daily News, Nuku'alofa, Tonga, June 24. Retrieved from http: / / www.tongadailynews.to/?p=6957

Tora, I. (2014). Nobles Hold the Key says Lord Ma'afu. Tonga Daily News, Nuku'alofa, Tonga, June 27. Retrieved from

http:/ / www.tongadailynews.to/?p=6985

Voltaire, F. M. (1748). Letter to Jeanne-Grace Bosc du Bouchet, Comtesse d'Argental, October 4.

Yurdusev, A. (2006). Thomas Hobbes and international relations: from realism to rationalism. Australian Journal of International Affairs, 60 (2): 305-321. 
